NBER WORKING PAPER SERIES

\title{
GROWING UP IN A RECESSION: BELIEFS AND THE MACROECONOMY
}

\author{
Paola Giuliano \\ Antonio Spilimbergo \\ Working Paper 15321 \\ http://www.nber.org/papers/w15321 \\ NATIONAL BUREAU OF ECONOMIC RESEARCH \\ 1050 Massachusetts Avenue \\ Cambridge, MA 02138 \\ September 2009
}

The views expressed in this paper are those of the authors and do not necessarily represent those of the IMF, its board of directors, or the National Bureau of Economic Research. We thank Marco Ottaviani and several anonymous referees for comments that substantially improved the paper. We also thank Antonio Ciccone, Claudia Goldin, Larry Katz, Bob Margo, Sarah Reber, David Romer, Jason Snyder, Romain Wacziarg, and Fabrizio Zilibotti, as well as participants at various conferences and seminars. We are very grateful to David Card, Liz Cascio, and Sarah Reber for providing data on the quality of education in the United States. Paola Giuliano gratefully acknowledges support from the Center for American Politics and Public Policy at UCLA and thanks the Russell Sage Foundation for its wonderful hospitality.

NBER working papers are circulated for discussion and comment purposes. They have not been peerreviewed or been subject to the review by the NBER Board of Directors that accompanies official NBER publications.

(C) 2009 by Paola Giuliano and Antonio Spilimbergo. All rights reserved. Short sections of text, not to exceed two paragraphs, may be quoted without explicit permission provided that full credit, including (C) notice, is given to the source. 
Growing Up in a Recession: Beliefs and the Macroeconomy

Paola Giuliano and Antonio Spilimbergo

NBER Working Paper No. 15321

September 2009, Revised November 2105

JEL No. E60,P16,Z13

\begin{abstract}
$\underline{\text { ABSTRACT }}$
Does the historical macroeconomic environment affect preferences for redistribution? We find that individuals who experienced a recession when young believe that success in life depends more on luck than effort, support more government redistribution, and tend to vote for left-wing parties. The effect of recessions on beliefs is long-lasting. We support our findings with evidence from three different datasets. First, we identify the effect of recessions on beliefs exploiting time and regional variation in macroeconomic conditions using data from the 1972-2010 General Social Survey. Our specifications control for nonlinear time-period, life-cycle, and cohort effects, as well as a host of background variables. Second, we rely on data from the National Longitudinal Survey of the High School Class of 1972 to corroborate the age-period-cohort specification and look at heterogeneous effects of experiencing a recession during early adulthood. Third, using data from the World Value Survey, we confirm our findings with a sample of 37 countries whose citizens experienced macroeconomic disasters at different points in history.
\end{abstract}

Paola Giuliano

Anderson School of Management

UCLA

110 Westwood Plaza

C517 Entrepreneurs Hall

Los Angeles, CA 90095-1481

and IZA

and also NBER

paola.giuliano@anderson.ucla.edu

Antonio Spilimbergo

International Monetary Fund

700 19th Street, N.W.

Washington, DC 20431

aspilimbergo@imf.org 


\section{Introduction}

Preferences for redistribution are at the foundation of political economy and vary in systematic ways across countries. ${ }^{2}$ Societies that prefer an equal distribution of income choose larger, more redistributive governments; societies that are less concerned about inequality choose smaller, less redistributive governments. For example, differences in preferences for redistribution can explain why government intervention in the production and distribution of income differs in Europe and the United States. ${ }^{3}$

Despite the crucial role of preferences for redistribution in explaining institutional outcomes, little empirical work has been done on how these preferences are formed and how and why they change over time. ${ }^{4}$ Are individual preferences for redistribution exogenous? Or is it possible that living in a specific macroeconomic environment leads to adaptation of preferences? This paper covers this gap by investigating whether experiencing a recession during youth permanently changes one's preferences for redistribution. ${ }^{5}$ Historical examples of the relevance of macroeconomic shocks on the determination of attitudes toward the state, and ultimately different welfare systems, abound. The national welfare system established in the United States after the Great Depression was a radical break from the strong sense of individualism and self-reliance characterizing American society. During the same period, several countries in Europe also moved from partial or selective provision of social services to relatively comprehensive coverage of the population.

In this paper, we examine systematically whether individuals differ in their desire for government intervention depending on the macroeconomic history they experienced when young, a question not yet addressed in the literature on preferences for redistribution. ${ }^{6}$ We do so by testing well-grounded psychological theories on the formation of political and economic beliefs. According to vast literature in social psychology, economic and political beliefs are formed mostly during early

\footnotetext{
2 Alesina and Glaeser (2004).

${ }^{3}$ For different models relating preferences for redistribution and political outcomes, see Piketty (1995), Alesina and Angeletos (2005), Corneo and Gruner (2002), and Benabou and Tirole (2006). For a general review of the literature on preferences for redistribution, see Alesina and Giuliano (2011).

${ }^{4}$ Part of the empirical literature on preferences for redistribution has emphasized the presence of systematic variation across cultures. Luttmer and Singhal (2011) show that preferences for redistribution of second-generation immigrants in different European countries tend to mirror those of their countries of origin. The intuition behind this result is that beliefs and values are passed down from parents to children, and they tend to persist from generation to generation. While culture is definitely important, it cannot explain why preferences for redistribution change over time.

5 Two recent papers provide evidence that preferences for redistribution can indeed change. Alesina and FuchsSchündeln (2008) show that strong collective experiences, such as the communist regime that existed in Eastern Germany before 1990, were relevant for the formation of preferences for redistribution of East Germans. Di Tella, Galiani, and Schargrodsky (2007) show that receiving property rights changes the beliefs that people hold. Karl Marx (1867) was probably the first to argue that the economy could influence beliefs and ideas in society.

${ }^{6}$ See Alesina and Giuliano (2011) for a review.
} 
adulthood and past this critical age change only slowly. The most relevant theory in this respect, the impressionable years hypothesis, states that core attitudes, beliefs, and values crystallize during a period of great mental plasticity in early adulthood (the so-called impressionable years) and remain largely unaltered thereafter. Evidence of significant socialization has been found between 18 and 25 years of age (Krosnick and Alwin, 1989). ${ }^{7,8}$

Consistent with theories of social psychology, this paper shows that large macroeconomic shocks experienced during the critical years of adolescence and early adulthood, between the ages of 18 and 25, shape preferences for redistribution and that this effect is statistically and economically significant.

We prove our results by using evidence drawn from three datasets. First, relying on pooled cross-sectional data from the 1972-2010 General Social Survey (GSS), we use regional variation in macroeconomic conditions in the United States to identify the impact of economic shocks on the formation of preferences for redistribution. The key challenge in any study of preference formation is the appropriate control of omitted variables: a cohort of individuals shares a large number of experiences, from economic shocks to technological progress to a multitude of unobservable characteristics. This makes the identification of macroeconomic shocks almost impossible if we use only cross-time variation. For this reason, our identification strategy hinges on cross-regional variation in individual experiences during the impressionable years. Using the information on respondents' location during adolescence, we rely on time- and location-specific shocks. This specification allows us to control for nonlinear time-period, and life-cycle and cohort effects, as well

\footnotetext{
7 The authors analyze data from two panel surveys in the National Election Study series. One panel interviewed a sample of 1,132 adults in 1956,1958, and 1960. The second panel interviewed a sample of 1,320 individuals in 1972, 1974, and 1976. The authors then divided the panel into various age groups: 18-25, 26-33, and so on. They find that people are most susceptible to political attitude changes during their early adult years, and that susceptibility drops off immediately thereafter. They do not control for other covariates and cannot disentangle the relevance of cohort versus age effects. Sample sizes for each age group were also fairly small. Other studies documented that the historical environment during the impressionable years shapes the basic values, attitudes, and world views of individuals (Cutler, 1974; Dennis, 1973; Easton and Dennis, 1969; Greenstein, 1965; Hess and Torney, 1967; Sears, 1975, 1981, 1983). Evidence of political socialization between ages 18 and 25 is also found by Newcomb, Koenig, Flacks, and Warwick (1967). Recent literature on neurological development illustrates differences between the adolescent and adult brain. Spear (2000) describes the adolescent brain in a transitional period, differing anatomically and neurochemically from the adult brain. In particular in the developing brain, the volume of gray matter in the cortex gradually increases until about the age of adolescence, then sharply declines as the brain prunes away neuronal connections that are deemed superfluous to the adult needs of the individual.

${ }^{8}$ A similar theory, the increasing persistence bypothesis, also maintains that individuals are flexible and responsive to social circumstances when they are young, but are gradually less responsive as they age. This decrease in flexibility is due to a "decline in energy and loss of brain tissue, to disengagement and a decrease in interest in events distant from one's immediate life, and to the accumulation of friends who share similar world views" (Glenn, 1980). Both hypotheses similarly predict that beliefs are formed mostly during adolescence and early adulthood and could eventually fade with age. Another hypothesis (which has received much less attention), the lifelong openness bypothesis, maintains that individuals are highly flexible throughout their lives and constantly alter their attitudes in response to changing life circumstances (Brim and Kagan, 1980).
} 
as a host of background variables and other time-varying regional characteristics, including level of wealth, differences in educational policies, overall level of inequality, and crime.

Second, we confirm the findings from the U.S.-based GSS by extending the analysis to a large set of countries. We do so by linking preferences for redistribution to experiences of economic disasters during youth in a sample of 37 countries, using evidence from the World Value Survey. Finally, we utilize data from the National Longitudinal Survey of the High School Class of 1972 (NLS72) to corroborate the age-period-cohort specification and shed light on the mechanisms driving the results.

For all our analysis, we use a variety of self-reported measures of preferences for government intervention. To show that subjective measures are a good approximation of underlying behavior, we also examine the validity of these self-reported measures by comparing them with several objective measures of political behavior, including political ideology, party affiliation, and voting behavior in the most recent election. The similarity of our findings on voting and political behavior confirms that experiencing a recession when young affects real behavior.

Overall, we find that experiencing a recession when young permanently increases the individual desire for redistribution. The effect is statistically significant and economically meaningful, and is robust across three different datasets and for a variety of specifications. To gauge the economic significance of our findings, we construct a counterfactual exercise, using evidence from the GSS, of what would have happened to the percentage of people voting for the Democratic Party in the most recent election in the nine U.S. regions, if individuals living in that region had not experienced a recession when young. ${ }^{9}$ We found that the effect of having individuals living through a recession when young could explain in some years up to 15 percent of the probability of voting for a Democratic presidential candidate in some U.S. regions.

In our empirical analysis, we also look at the presence of heterogeneous effects. Overall, we find that the effect of experiencing a recession when young is quite general and persistent, with a slightly stronger effect for less educated and poorer people. This evidence suggests that at least part of the recession effect is amplified by the personal conditions of the individuals during the recession.

Our findings are consistent with three broad interpretations. First, evidence from social psychology (and also neuroscience) shows that young adults are particularly responsive to the external environment, implying that later experiences are less relevant in shaping behavior. Our evidence also concurs with work in economics on learning from experience (Malmendier and Nagel, 2011, 2013). Whereas standard models in economics assume that individuals are endowed with

9 The details of this counterfactual exercise are provided in Section 2.6. 
stable preferences and incorporate all historical data when forming beliefs, learning from experience models, drawing on evidence from psychology, predict that personal experiences, rather than the analysis of all available historical data, exert a greater influence in the formation of beliefs. If individuals tend to put a higher weight on realizations of macroeconomic conditions experienced during their lifetime compared with other available historical data, an important implication of learning from experience is that young individuals react more strongly to a macroeconomic shock than older individuals because recent experiences make up a larger part of their lifetime so far.

A second interpretation regarding the persistent effect of macroeconomic shocks on beliefs is consistent with Cogley and Sargent (2008). The authors argue, in reference to the Great Depression, that macroeconomic shocks are "beliefs-twisting events," whose influence can last long, because it takes a long time to correct the pessimistic beliefs induced by the depression, through the observation of macroeconomic data. ${ }^{10}$ Since the 1930 s, many writers have indeed argued informally that the Great Depression created a "depression generation," whose behavior affected the macroeconomy for decades after the depression ended. For example, Friedman and Schwartz (1963) suggested that the Great Depression "shattered" beliefs in the future of capitalism. Our findings are consistent with this view.

A third interpretation is consistent with theoretical work by Piketty (1995): the author argues that shocks could change people's belief about the relative importance of luck versus effort as a driver of success. This belief, in his model, is related to the amount of taxes that people vote for and their preferences for government intervention. We find evidence consistent with his theory: the uncertainty created by macroeconomic shocks makes people believe that luck is more relevant than effort and, as a result, increases their desire for government intervention.

Our paper brings together various strands of literature. We incorporate findings of social psychology (Krosnick and Alwin, 1989) about the relevance of a specific age range in the determination of preferences for redistribution. We also contribute to the growing empirical literature on the determinants of beliefs. This literature has studied various determinants, including the relevance of property rights (Di Tella, Galiani, and Schargrosky, 2007) ${ }^{11}$ and crime (Di Tella, Donna, and McCulloch, 2007) on beliefs, the relationship between dependency on oil and individualism (Di Tella, Dubra, and McCulloch, 2010), the importance of political regimes (Alesina

\footnotetext{
${ }^{10}$ Cogley and Sargent (2008) do not have any data on beliefs; they argue that a beliefs-twisting story could help to explain macro time series.

11 The authors find that squatters in Buenos Aires, who were randomly assigned property rights, developed beliefs more favorable toward a capitalistic society, as represented by beliefs on individualism, materialism, and the role of merit and trust.
} 
and Fuchs-Schuendeln, 2008) and culture (Luttmer and Singhal, 2011). Further, we are the first to investigate the importance of macroeconomic conditions during one specific age period in the determination of beliefs.

Our paper is also related to the literature analyzing the determinants of preferences for redistribution more generally. ${ }^{12}$ Models based on a cost-benefit analysis emphasize the relevance of individual measures of current (or expected future) income and individual economic motives more broadly — a rich person living in a poor neighborhood, for example, may favor state intervention because he or she benefits from public goods provided in the region ${ }^{13}$; today's poor, who expect to be rich tomorrow, might not like redistributive policies because they will have to support them rather than benefit from them in the future (Ravallion and Lokshin, 2000). For the so-called "publicvalue approach," ${ }^{14}$ what matters are idiosyncratic beliefs about the importance of luck versus effort as a driver of economic success (Piketty, 1995), fairness (Alesina and Angeletos, 2005) or beliefs in a just world (Benabou and Tirole, 2006). Our paper is related to this literature, as it shows that living under a specific macroeconomic environment when young leads to adaptation of preferences.

Finally, the paper relates to the literature on the implications of macroeconomic shocks on economic outcomes. Shocks may have long-lasting effects on labor market outcomes (Oreopoulos et al., 2012; Kahn, 2010) or participation in the stock market (Malmendier and Nagel, 2011). ${ }^{15}$ Several papers in corporate finance and household finance look at the importance of recent returns on young investors in the 1990s (Greenwood and Nagel, 2009; Vissing-Jorgensen, 2002). Graham and Narasimhan (2004) find that corporate managers who lived through the Great Depression choose a more conservative capital structure.

This paper is organized as follows. Section 2 describes the data and the empirical strategy for the GSS. Section 3 presents the cross-country analysis. Section 4 looks at the longitudinal evidence drawn from the NLS72. Section 5 investigates the presence of heterogeneous effects, and Section 6 concludes.

\section{Evidence from the General Social Survey}

Our primary dataset on individual and political beliefs is the General Social Survey (GSS), which provides repeated cross-section observations on political and economic beliefs and various

\footnotetext{
${ }^{12}$ For a general review of the literature on preferences for redistribution, see Alesina and Giuliano (2011).

${ }^{13}$ Along these lines, Luttmer (2001) shows that preferences for redistribution increase when the share of local welfare recipients from one's own racial group increases.

14 See Corneo and Gruner (2002).

15 Recessions are also relevant for babies' health (Deejia and Lleras-Muney, 2004), fertility (Ben-Porath, 1973), and adult health-related behavior (Ruhm, 2000).
} 
individual characteristics. The GSS, conducted by the National Opinion Research Center at the University of Chicago, is a nationally representative sample for the United States of about 1,500 respondents each year from 1972 through 1993 (except for 1979, 1981, and 1992). It continues biennially, with 3,000 observations from 1994 to 2004, 4,500 observations in 2006, and 2,000 observations in 2008 and 2010. ${ }^{16}$ We use all the data available from 1972 to 2010. Descriptive statistics for our sample are presented in Table A1.

\subsection{Empirical analysis}

The key variables for our analysis are several measures of preferences for redistribution and political behavior as dependent variables and a regional measure of macroeconomic shock as an explanatory variable. As measures for preferences for redistribution, we use the answers to three questions:

1. "Some people think that the government in Washington should do everything to improve the standard of living of all poor Americans (they are at point 5 on this card). Other people think it is not the government's responsibility, and that each person should take care of himself (they are at point 1). Where are you placing yourself in this scale?" This is referred to as "belp poor."

2. "We are faced with many problems in this country, none of which can be solved easily or inexpensively. I am going to name some of these problems, and for each one I would like you to tell me whether you think we are spending too much money on it, too little money or about the right amount." A list of items follows, including "assistance to the poor." We coded the variable so that a higher number indicates too little assistance to the poor. This is named "assistance poor."

3. "Some people say that people get ahead by their own hard work; others say that lucky breaks or help from other people are more important. Which do you think is most important?" The answer can take a value from 1 to 3: hard work is most important (1), hard work and luck are equally important (2), luck is most important (3). This is referred to as "work-luck."

The rationale of the first two variables is clear. The theoretical motivation for using the last variable is that an individual who believes that luck is the major determinant of economic success is expected to favor government redistribution; in contrast, an individual who believes in the

${ }^{16}$ The survey is conducted face-to-face with an in-person interview by the National Opinion Research Center at the University of Chicago of a randomly selected sample of adults (18 and older) who are not institutionalized. The survey takes about 90 minutes to administer. For detailed information on the GSS, see http://www.norc.org/GSS+Website/. Sampling weights are used to adjust for differences in sampling frame across years. 
importance of personal hard work is expected to oppose redistribution as discussed above (Piketty, 1995).

One concern when interpreting questions on preferences for redistribution is whether they are an accurate measure of underlying preferences. If self-reported preferences for redistribution reflect underlying preferences, then they should correspond to voting behavior and political ideology. We examine the validity of self-reported measures by looking at three different measures of political behavior corresponding to the following three questions:

1. "We hear a lot of talk these days about liberals and conservatives. I am going to show you a seven-point scale on which the political views that people might hold are arranged from extremely liberal to extremely conservative. Where would you place yourself in this scale?" We coded the question so that a higher number corresponds to extremely liberal. The answer to the question is referred to as "political ideology."

2. "Generally speaking, do you usually think of yourself as a Republican, Democrat, Independent, or what?" The answer could take a value from 6 to 0: strong Democrat (6), not very strong Democrat (5), Independent, close to Democrat (4), Independent (3), Independent, close to Republican (2), not very Strong Republican (1), strong Republican (0). We dropped from the analysis people who answered "Other party, refused to say" or "Don't know." 17 The answer to this question is referred to as "party affiliation."

3. The third political measure, voting Democrat, is based on whether the respondent voted for a Democratic presidential candidate in the most recent election. We eliminated those observations where individuals either did not vote or voted for an independent candidate.

We use as a measure of macroeconomic shocks large, regional recessions (as opposed to statewide recessions). The GSS contains information on census regions (but not on single states) in which the person was living when he or she was 16 . We use this information to match individuals with the macroeconomic shock in the region where the person was living during his or her youth. ${ }^{18}$ We assume that the individual was living during his or her "impressionable years" in the region where he or she was living at 16 . One problem with assigning the region of residence at 16 to the whole "impressionable years" period is that people could have moved during that period. The extent to which people moved during their impressionable years introduces a measurement error that could

\footnotetext{
17 We also run the regressions by excluding from the analysis people who answered "independent" without any indication of whether they are close to Republican or Democrat. Our results are robust to this exclusion.

${ }^{18}$ For a list of the nine macro regions, see the online appendix.
} 
bias our results toward zero. We address this problem by running our regressions on a subsample of individuals who lived, at the time of interview, in the same region where they lived at 16 . We discuss the differences in results below. In addition, the longitudinal analysis (for which individuals' locations during and after their "impressionable years" are known) confirms our results. Finally, the results are also valid in the cross-country analysis, where we run the regressions on the sample of people who have been living in the same country throughout their lives.

To have the longest possible time series, we construct a measure of regional recessions using data on regional personal income from the Bureau of Economic Analysis (BEA). The BEA has been providing annual estimates of per capita personal income at the state level since $1929 .{ }^{19} \mathrm{We}$ construct a measure of real per capita personal income using data on state personal income and population data, adjusted for inflation..$^{20}$ For our dependent variable, we construct a variable equal to 1 if the individual experienced at least one year in which the real regional per capita GDP growth was lower than -3.4 percent during his or her "impressionable years" and zero otherwise. This threshold represents the lowest $10^{\text {th }}$ percentile of the GDP growth distribution for the nine U.S. regions from 1929 to $2010 .^{21}$

Figure A1 shows whether individuals living in a certain region experienced a recession during their impressionable years, by year of birth. The macroeconomic experiences of individuals living in different regions during their impressionable years varied greatly. For example, the cohorts born between 1933 and 1940 were subject to at least one year of recession if they lived in the New England, East North Central, or South Atlantic regions, but not if they lived in the other regions. ${ }^{22}$ The cohorts born between 1960 and 1970 experienced widely differing fates: as young adults, those who lived in New England experienced no recession, but those in other regions weren't so fortunate. Around 30 percent of those who spent their impressionable years in the East (north or south) Central region lived through a recession, as did about half in the Middle Atlantic, Southern Atlantic,

\footnotetext{
19 The BEA also compiles data on gross state product, i.e., GDP at the regional level, but dating back only to 1963 . The correlation between real per capita personal income and real per capita GDP is 0.92 . We could also have used regional unemployment rates as a measure of macroeconomic recessions; however, this variable is available only since 1968, from the BLS. As a result, we would lose too many observations. In the longitudinal analysis (which covers 1972 to 1986), we can use measures of state unemployment rates. We found that the results using unemployment are stronger when compared to measures of recession based on GDP.

${ }^{20}$ We use national CPI to correct for inflation.

${ }^{21}$ We choose the lowest $10^{\text {th }}$ percentile rather than simply negative GDP growth because 80 percent of the individuals experienced at least one year of negative growth during their critical age period in our sample when using this definition; therefore, a shock simply defined as negative growth would not have given enough variation. We could have used also the fifth-lowest percentile (corresponding to a growth rate lower than -8.4 percent), but the problem with that measure is that it captures only the generation who experienced a recession between 1929 and 1947.

22 Only people born between 1933 and 1936 experienced a recession in the Southern Atlantic region.
} 
and Mountain regions; 70 percent in the West North Central region, and a whopping 90 percent who lived in the Pacific or West South Central regions.

Our baseline specification is the following:

Beliefs $_{\text {irt }}=\alpha_{0}+\alpha_{1}$ macro shock $k_{r 16, \text { imp.years }}+\alpha_{2} X_{i}+\beta_{a}+\delta_{r}+\eta_{t}+\gamma_{r 16}+\gamma_{r 16} *$ age $+\varepsilon_{\text {irt }}$

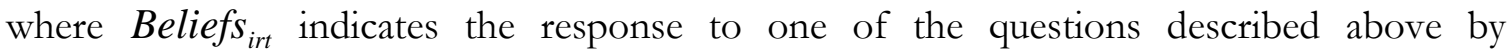
individual $i$, interviewed at time $t$ in region $r$. The variable macro shock $k_{\mathrm{r} 16 \text {, imp.years }}$ is a dummy indicating whether the individual experienced a recession during the impressionable years in his or her region of residence at 16 , which we use as a reference region for the whole $18-25$ range. $X_{i}$ is a vector of individual characteristics, including gender and race, as well as measures of income, education, marital status, and labor market status. In some specifications, we also include information on family background of the individual at 16 , and religious denomination. In particular, we control for both the level of education of the father and family income at 16, the religion in which the person was raised, and the religion at time of interview.

All specifications include age dummies $\left(\beta_{a}\right)$ and time fixed effects $\left(\eta_{t}\right)$ to control for agespecific trends in beliefs and common national history. We also include dummies for both the region where the person is living $\left(\delta_{r}\right)$ and the region where the person was at $16\left(\gamma_{r 16}\right)$. This helps to control for regional ideology, both at birth and later on, and anything specific to a certain region of origin or residence that could be driving differences in beliefs. ${ }^{23}$ All our regressions also include interactions of region-at-16 dummies with linear age trends $\left(\gamma_{r 16} * a g e\right)$ to help rule out the possibility that results are driven by region-specific cohort effects.

All regressions are estimated using OLS for ease of interpretation, but similar results are obtained with ordered logit or probit (depending on the specification). Standard errors are clustered at the region-at-16 level. Because of the small number of clusters, we correct the standard errors using the "wild bootstrap" procedure suggested by Cameron, Gelbach, and Miller (2008) ${ }^{24}$. Descriptive statistics for all our measures are reported in Table A1 of the appendix.

\footnotetext{
${ }^{23}$ The region at time of interview does not correspond necessarily to the region $(r 16)$ in which the individual grew up, as individuals may have moved.

${ }^{24}$ Computing valid confidence intervals with so few clusters is a hard problem. Our results are also robust to clustering at the region*year level.
} 
A few issues on the identification should be discussed beforehand. First, our variable of interest, macro shock $k_{\mathrm{r} 16 \text {,imp.years }}$, exhibits cross-regional variation but also variation between cohorts. To control for any omitted variable that exhibits cohort-level variation, in the less parsimonious specification, we also include an almost full set of cohort dummies. ${ }^{25}$

Second, recent region-specific trends could be driving the results. In the less parsimonious specification, we also control for this possibility by including a full set of region of interview and year interactions.

Third, the identification of the effects of macro shocks on beliefs comes from the fact that different regions experienced different shocks over the years. The problem with this approach is that we could attribute to the regional macroeconomic shock the effect of some other time-varying regional characteristics, since the macroeconomic shock is the only time-varying regional regressor included in our baseline specification.

Region-at-16 dummies interacted with age linear trends in all specifications partially address this identification concern. In addition (in the robustness section of the paper), we also control for a large number of region-specific time-varying characteristics that could be correlated with macroeconomic shocks, including various measures of crime, income inequality, educational policies, and proxies for wealth. In the same section, we also run a series of placebo exercises to make the identification strategy more credible.

Macroeconomic shocks may also have an effect on an individual's endowment through education, income, or differences in labor market experiences, for example. Individual endowments, in turn, are known to be an important variable in explaining the formation of beliefs (Di Tella, Galiani, and Schargrodsky, 2007). Therefore, macroeconomic shocks may influence adult beliefs through both the direct channel discussed above and the indirect channel of individual endowment. In order to control for the endowment effect, we introduce individual characteristics at the time of the interview and family background controls (described above). In addition, we construct regionspecific measures of wealth and educational policies for the "impressionable years" period. Finally, when using the panel analysis, we are able to control directly for the endowment effect as the NLS72 follows individuals during their formative age, therefore allowing us to control directly for their level of education, income, and labor market experience.

Tables 1-3 report the results for preferences for redistribution (columns 1 and 3) and political ideology and behavior (columns 4-6) under a variety of specifications. In each table

25 The problem with working solely with cross-regional variation is that sometimes it could not give us enough statistical power to estimate the parameters with sufficient precision. 
(columns 7-9), we also report the estimated average effect size (AES) coefficients. We computed the AES following Kling, Liebman, Katz, and Sanbomatsu (2004). Let $\beta^{k}$ indicate the estimated recession coefficient for the outcome variable $k$, and let $\sigma^{k}$ denote the standard deviation of outcome k. Then, the AES is equal to $\frac{1}{K} \sum_{k=1}^{K} \frac{\beta^{k}}{\sigma^{k}}$, where $K$ is the total number of outcome variables. ${ }^{26}$ AES estimates have two advantages: whereas results on each single question could potentially be due to chance (Type I error), this is less likely when several questions are simultaneously summarized in an index. Moreover, the use of indices could also reduce the risk of low statistical power (Type II error). We report three sets of AES estimates: one for preferences for redistribution (combining the three measures on preferences for redistribution), one for political behavior (combining the three measures on political behavior), and one for the six variables all together.

We run three different specifications. The baseline specification (reported in Table 1) includes current region and year-of-interview fixed effects to control for nationwide and regionspecific effects, and region-at-16 fixed effects to rule out the possibility of capturing something specific to a certain region of origin that could drive differences in beliefs. In addition, this specification also controls for basic demographics (gender, race, and age dummies), together with employment and marital status, education, and dummies for family income. This second group of variables controls for those variables that could have been influenced by a recession during the formative years. ${ }^{27}$ The specification also includes interactions of region-at-16 dummies with linear age trends.

Table 2 adds to the baseline specification cohort effects, ${ }^{28}$ whereas Table 3 is the most demanding specification. It adds to the specification of Table 2 two additional variables, meant to capture the status of the person when he or she was 16: a nonparametric specification of the family income variable at 16 (with the inclusion of five dummies) ${ }^{29}$ and the level of education of the father

\footnotetext{
${ }^{26}$ To properly calculate the sample variance of AES, the coefficients $\beta^{k}$ are jointly estimated in a seemingly unrelated regression framework. See Clinginsmith, Khwaja, and Kremer (2009) for an alternative application and further details.

${ }^{27}$ Employment status is defined using a dummy indicating whether the person is unemployed; we control for marital status with a dummy indicating whether the person is married. Education is measured using number of years of education. We control for income in a nonparametric way by including 12 income dummies. For a precise definition of the income brackets, see the online appendix.

${ }^{28}$ In a single cross-section, age, year, and cohort dummies are perfectly collinear and cannot be included all together. In a repeated cross section, few cohorts could not be captured by the age and year dummies. In our specification, we add as many cohort dummies as possible up to the point that age, time, and cohort dummies are not perfectly collinear.

${ }^{29}$ The variable on the income of the family when the person was 16 is defined as follows: "Think about the time when you were 16 years old. Compared with American families in general then, would you say your family income was far below average, below average, average, above average, or far above average?"
} 
(given by the number of years of education). ${ }^{30}$ These variables are meant to capture individual characteristics, which could be correlated with frequency of regional economic shocks. ${ }^{31}$ The specification also controls for the religion of the person at 16 and at time of interview. Religious beliefs could be important in the determination of beliefs about the poor and consequently drive preferences for redistribution. ${ }^{32}$ Finally, the specification also includes all interactions between region of interview and year effects to take into account all possible region-of-residence and time-varying covariates.

\subsection{Results}

The first three columns of Table 1 report the regressions for preferences for redistribution. We coded the variables so that a positive coefficient means a higher preference for government redistribution. The coefficient on the variable indicating whether the person experienced a recession during his or her impressionable years is significant at least at the 5 percent level. The significance level increases to 1 percent for political behavior and ideology and when AES are used.

To assess the magnitude of our results, we calculate the beta coefficients ${ }^{33}$ (they are reported in Table A15). A one standard deviation increase in our shock measure is associated with an increase of 0.014 standard deviations of the preferences for redistribution variable. The result is about twothirds of the effect of being unemployed, but much smaller than the effect of race or education. ${ }^{34}$ Our specification is particularly demanding and has the advantage of precisely identifying the effect of macroeconomic shocks on beliefs while controlling for age, time, and cohort effects, together with a large set of individual controls. In Section 2.6, we perform some exercises to give a sense of the aggregate relevance of living through a recession. When we look at the aggregate effect, the recession experience is much more important in terms of magnitude, despite the relatively small regression coefficient in the individual-level regressions.

The coefficients on the other variables are consistent with the previous literature. Educated, married, male, and high-income-earning individuals are less favorable to redistribution. Race is an

\footnotetext{
30 There is also a question on the level of education of the mother, but the number of missing values is much higher than the variable on the level of education of the father.

31 The number of observations is smaller in Table 3 due to a higher number of missing observations.

${ }^{32}$ For both religion at time of interview and religion when growing up, we include five dummies: Protestant, Catholic, Christian, Jewish, and Other. The excluded group is given by nonreligious individuals.

${ }_{33}$ Beta coefficients are the estimates resulting from an analysis carried out on independent variables that have been standardized so that their variance is 1 . They refer to how many standard deviations a dependent variable will change, per standard deviation increase in the predictor variable.

34 The coefficient of race on preferences for redistribution has always had the largest effect in the literature (see, for example, Alesina and Glaeser, 2004; Alesina and Giuliano, 2011; and Luttmer, 2001).
} 
important factor in determining individual preferences for redistribution (Alesina and La Ferrara, 2005)..$^{35}$

In columns 4-6, we report the results for political views and political behavior. The coefficients are estimated more precisely; in addition, the relative magnitudes of the recession coefficients are higher. For example, the relevance of economic shocks is four times the effect of being unemployed and comparable to the effect of education. As before, the effect of a recession is smaller than the effect of race (with the exception of the question on political ideology, where the results are of similar magnitude). ${ }^{36}$ The signs of the coefficients are consistent with the literature. Women tend to be more left-wing, as do unemployed people and African Americans. Education could have different effects: more educated people are more likely to be affiliated with the Republican Party but may at the same time define themselves as more liberal (there does not seem to be an effect of education on voting behavior). ${ }^{37}$

Table 2 reports the results by adding a set of cohort dummies. The results are very similar to the baseline specification, with the exception of the variable work-luck and assistance poor, where we lose some power but the coefficient is of similar magnitude and still significant at the 10 percent level.

Table 3 reports the results, including family background controls, cohort effects, and regionyear interactions. ${ }^{38}$ Family background at age 16 is relevant in the determination of preferences for redistribution. In particular, a higher family income when young reduces the desire for redistribution, similarly to what we find for current family income. Years of education of the father have a similar effect as one's own education. This variable is negatively correlated with preferences for redistribution (with the exception of the work-luck variable and political views ${ }^{39}$ ) and political behavior. ${ }^{40}$ Among the religious denominations, Protestants, Catholics, and Christians are less inclined to favor redistribution and tend to be more to the right on the political spectrum, whereas

\footnotetext{
${ }^{35}$ Note that the male dummy has a positive effect on the belief that luck is more important than effort. This result is confirmed in the U.S. longitudinal analysis but is not present in the cross-country regressions. Education also appears to have a positive sign in the work-luck variable, but we do not find similar results in the longitudinal analysis or the crosscountry analysis.

${ }^{36}$ See beta coefficients reported in Table A15.

37 The discrepancy could be due to a different position on social and economic issues. The result of education on voting behavior is positive in the specification of Table 3 .

${ }^{38}$ In the appendix, we also report the results of a specification adding only additional family background controls to the baseline specification (Table A2). The results are very similar to the specification of Table 3 .

39 We find a similar result for the effect of father's education on the work-luck belief in the longitudinal analysis.

${ }^{40}$ Father's education and own education go in opposite direction only in the determination of voting Democrat.
} 
being raised Jewish increases the desire to redistribute from the rich to the poor. ${ }^{41}$ This most demanding specification does not change the nature of our results.

\subsection{Restricting the sample to non-movers}

In the regressions above, we use the region of residence at 16 to determine the region of residence for the whole "impressionable years" period. This may introduce some measurement error, because some individuals could have moved from the region of residence at 16 during their "impressionable years." ${ }^{42}$ In Tables A3-A6 of the appendix, we repeat the specifications of Tables $1-2$, restricting the sample to non-movers. ${ }^{43}$ The results are very similar in terms of magnitude when compared to the results from the whole sample, but they are more precisely estimated, showing that measurement error indeed is weakening our results.

\section{4. "Impressionable years" versus other years}

Following the social-psychology literature, our analysis focuses on the role of “impressionable years" (between 18 and 25) in the formation of beliefs (Mannheim, 1952; Krosnick and Awin, 1989). In this section, we test whether individuals constantly alter their attitudes in response to changing life circumstances by looking at the impact of recessions during other age ranges. In addition, we also test whether the sensitivity to recessions during the impressionable years declines with age.

In Table 4 we report the results for other age ranges. We repeat our baseline specification (Table 1) based on different eight-year range intervals $(2-9,10-17,26-33,34-41,42-49$ and 5057). ${ }^{44}$ The table reports the coefficients on the variable indicating whether the individual experienced at least one recession at different ages. ${ }^{45}$ Being exposed to a recession before the age of 17 or after age 25 has little or no impact on beliefs. The formative period between the ages of 18 and 25 is the age during which the majority of beliefs under consideration are formed. The period between 26 and 33 is also relevant for the formation of political beliefs (this is true for each individual variable on

\footnotetext{
${ }^{41}$ These results hold only for some of the variables on preferences for redistribution and political behavior.

${ }^{42}$ However, this is, in practice, mitigated if most of the movers move within the same macro region and therefore experience the same macro shock.

${ }^{43}$ We define non-mover as an individual whose region of residence at 16 is the same as the region of residence at time of interview. We consider these people as non-movers, but they could have moved between the age of 16 and the time of interview.

${ }^{44}$ We chose intervals of equal length in order to be consistent with the impressionable years range. We also report a specification for an age period centered around 16 (between 14 and 18). During this period, the probability of moving away for college, for example, should be lower.

${ }^{45}$ For each age range, we also run a specification in which we always include the macroeconomic shock during the impressionable years (Table A8, and Table A9 when restricted to non-movers) together with the shock in any of the other age ranges. The shock experienced between 18 and 25 is always significant in a horse race with the macroeconomic shock experienced in a different period of life.
} 
political behavior and for the AES estimates), providing some support for the increasing persistence bypothesis theory, at least in the case of political behavior. ${ }^{46}$

Given the nature of the dataset, it is difficult to compare the importance of the impressionable years versus other periods of life. The GSS provides information only on the region where an individual lived at 16-the further removed the time period from that age, the higher the measurement error. To limit this problem, we also run the regressions for other age ranges by limiting the sample to nonmovers (the results are reported in Table A7). ${ }^{47}$ The results are very similar to those of the whole sample.

Given the relevance of the impressionable years, one interesting question is how much the effect of experiencing a macroeconomic shock when young on preferences for redistribution and political behavior declines with age. To study the speed at which beliefs diminishes with age, we look at the interaction between experiencing a shock during the impressionable years and the age of the person. The results are reported in Table A10 of the appendix. While we find that the result is strong for the impressionable years, the effect fades with time, especially for political behavior. ${ }^{48}$ This effect is not present when we look at preferences for redistribution (with the exception of the variable assistance poor, where there is some evidence of its effect declining with age). The declining effect for political behavior is in line with the increasing persistence bypothesis theory, which states that the period between 18 and 25 is the most relevant for the formation of beliefs, but the effect could fade slowly (though not completely) with age.

\subsection{Additional robustness checks}

A potential concern with our estimates reported up to this point is that the macroeconomic shock is the only regressor that varies at the regional level during the impressionable years. This makes the identification problematic, because cohort effects at the regional level may still be confounding factors in the estimation of the effect of a regional recession.

To solve this concern, we construct several regional time varying characteristics that could be correlated with macroeconomics shocks or that could be driving the formation of preferences for redistribution.

We start by including in our regressions two measures of crime (property and violent crime). Crime may change people's beliefs on how the economy works. Di Tella, Donna, and MacCulloch

\footnotetext{
${ }^{46}$ Recessions experienced during this period also appear to be relevant for the formation of the belief regarding the importance of luck as a determinant of success. The results on the period between ages 26 and 33, however, disappear in a horse race between this period and the impressionable years.

${ }^{47}$ Table A9 for the results reporting the horse race between impressionable years and other age ranges.

${ }^{48}$ This is in line with the results obtained when we run the regressions on other age ranges.
} 
(2008) have analyzed the relationship between crime and ideological beliefs in Latin America. The authors find that people who were victimized report believing that the distribution of income is unfair, and they disagree with the idea that privatization has been good for the country.

The second set of controls includes a variety of measures on educational policies and quality of education. In particular, we control for time-varying measures of pupil-teacher ratio, average teacher salary, and per pupil expenditures. Differences in school spending and quality of education could be relevant for the formation of preferences for redistribution through various channels. A recent literature has investigated how differences in school spending could be correlated with inequality. ${ }^{49}$ Another channel is returns to education. Card and Krueger (1992) show that returns to education are higher for individuals who attended schools with lower pupil-teacher ratios and higher relative teacher salaries. If macroeconomic shocks are correlated with differences in educational policies or quality of education, they could pick up the effect of these variables in the formation of preferences for redistribution.

As a third robustness check, we include home ownership. Ideally, we would like to control for measures of wealth at the regional level to rule out the possibility that the effect of a recession on preferences for redistribution is mediated by an endowment effect. Measures of wealth at the regional or state level on a yearly basis do not exist, due to the lack of surveys on individual wealth going so far back in time and large enough to split the sample by state. Although not ideal, home ownership could partially address the endowment effect being one of the sources of wealth most affected by recessions.

As last time varying controls we include two other macroeconomic variables: a measure of wage inequality and the average per capita GDP growth. Recessions could be related to changes in inequality; therefore, preferences for redistribution could simply be a reaction to the new level of inequality rather than to the macroeconomic shock per se. Finally, we include GDP growth to show that large recessions still have an effect on belief formation even when linearly controlling for GDP growth in a given region ${ }^{50}$.

\footnotetext{
49 The correlation between inequality and educational policies has mixed findings: Goldin and Katz (2008) find that income inequality slowed the establishment of public high schools from 1910 to 1938, while Boustan et al. (2012) and Corcoran and Evans (2010) show that more recent increases in income inequality at the local level, from 1970 to 2000 , increased locally generated elementary and secondary school revenues.

${ }^{50}$ Results are reported in Table A11. The sources and method of construction of all control variables are documented in the online appendix. Table A11 also shows the results where all controls are included in the same specification.
} 
Although some of the above-mentioned controls have an effect on preferences for redistribution and political behavior in line with what is established in the literature, ${ }^{51}$ in all the specifications macroeconomic shocks maintain an effect significant and similar in magnitude to the baseline specification.

As a second set of robustness checks, we perform two different placebo exercises. The first placebo consists of examining how our identification strategy performs on placebo macroeconomic conditions. We create the placebo by imputing a random neighboring region to every individual and verify that the effect of the macroeconomic shock becomes insignificant. The second placebo consists of studying the effect of economic shocks on beliefs that should not be related to regional macroeconomic conditions: differences in macroeconomic experiences during formative age should indeed matter only for economic and political beliefs and not for other types of beliefs. We replicate our baseline framework using a set of beliefs concerning spiritual life or attitudes toward homosexuality (as a proxy for other types of liberal beliefs) as dependent variables. The first is measured by a question regarding feelings about the image of the world (possible answers, on a scale of 1 to 7, range from "the world is filled with sin (1), to "there is much goodness, which hints at God's goodness (7)”.) Beliefs about homosexuality are measured by three different questions. One asks the respondents whether homosexual sex relations are always wrong (1), almost always wrong (2), sometimes wrong (3), or not wrong at all (4). The other two additional questions ask respondents whether they believe that homosexuals should be allowed to speak or teach (the answers are assigned a value of 1 for yes and zero for no). ${ }^{52}$ Tables A12 and A13 present the results of both placebos. Fictitious macroeconomic conditions have no effects on preferences for redistribution or political behavior ${ }^{53}$. Experiencing a recession has no significant impact on other types of liberal versus conservative beliefs or beliefs concerning spiritual life. By contrast, other individual variables have a strong, expected impact on these types of beliefs.

\subsection{An aggregate perspective}

Our estimation uses cross-sectional differences in regional economic conditions to estimate the impact of recessions on beliefs. By including cohort, age, and year-of-interview fixed effects,

\footnotetext{
51 An increase in the level of crime moves people to the right in terms of political ideology (it also has an opposite effect on preferences for redistribution, but the results are not robust across specifications and different variables). A low level of educational quality as measured by pupil-teacher ratio and teacher salaries (although less robust) increases the desire for redistribution. A higher level of wage inequality during the impressionable years is positively correlated with a higher desire for redistribution and a left-wing ideology. An increase in home ownership reduces the desire for redistribution, but the results are not robust across different variables. The effect is also not significant in the NLS72, where it is more precisely estimated. Home ownership in the region where one grew up does not affect political ideology.

52 For each of these variables, we follow the baseline specification in the paper.

${ }^{53}$ In few specifications the effects are sizeable but not significant at conventional levels.
} 
together with a large set of individuals and family controls, our specification has the advantage of isolating the impact of recessions on preferences for redistribution and political behavior. In this section, we provide an aggregate perspective on the importance of macroeconomic shocks on preferences for redistribution and political behavior by constructing a counterfactual exercise-what would have happened to the distribution of political behavior across the nine U.S. regions if people had not experienced a recession during the impressionable years. To do this, we first construct fitted values for the variable "voting for the Democratic Party" using the specification of Table 2. We next construct a counterfactual series for political behavior without heterogeneous effects of recession (by falsely assuming a coefficient equal to zero for the recession variable, $\alpha_{1}$ in equation 1). Summing up across individuals within each region at each time of interview allows us to compare the evolution of political behavior with and without the effect of experiencing a recession during the impressionable years. In Figure 1, for each region, we plot the ratio of fitted regional political behavior (from column 6 of Table 2) to the counterfactual regional political behavior obtained by setting the economic shock coefficient to zero. The fitted-counterfactual ratio has been multiplied by 100 to be expressed as a percentage. Deviations from a value of 100 are attributable to the heterogeneous effects for the population of that region in one specific interview year of living through a recession when young. Since we control for year of interview, age, and cohort fixed effects, together with region of residence at 16, region-of-interview fixed effects, and individual controls, the difference between the fitted and counterfactual series can identify only the heterogeneous effects of having different individuals with different macroeconomic experiences during the impressionable years in each region. The result on the "voting Democrat" variable shows a consistent picture. Having people who experienced a recession when young affected the probability of voting for the Democratic Party in a sizeable matter in each region of the United States. The effect, which could be as large as 15 percent, was more pronounced during the 1970s and 1980s. This is not surprising, as people living in these regions during this period were young during the Great Depression.

A similar result performed on the other beliefs gives a consistent picture, ${ }^{54}$ with the magnitude of the effect declining over time and with the effect on political beliefs being generally larger than the one on preferences for redistribution. ${ }^{55}$

\footnotetext{
54 The effect on preferences for redistribution explains, on average, between 3 percent and 10 percent of the effect, depending on the variable. The effect on political ideology and party affiliation is closer to the effect of voting for the Democratic Party. The results are available from the authors.

55 In the appendix, we also report the results of a different exercise, whose goal is to gauge whether the time variation in average demographics is smaller relative to the time variation in average recession experience. We do so by collapsing the
} 


\section{Evidence from the World Value Survey}

We now turn to our specification that examines differences in macroeconomic conditions using cross-country evidence. The analysis is relevant in showing that results similar to those found in the United States exist when we replicate our analysis across countries. The analysis relies on data from the World Value Survey (WVS), a compilation of national, individual-level surveys on a wide variety of topics, including preferences for redistribution and political behavior. The survey also contains information on standard demographic characteristics, such as gender, age, education, labor market status, and income. The survey has been carried out five times (1981-1984, 1990-1993, 1995-1997, 1999-2004, and 2005-2007). The coverage varies depending on the wave, from 22 countries in 1980 to 81 countries in the fourth wave. The fifth wave was carried out in 57 countries.

The WVS contains a richer set of questions on preferences for redistribution or preferences for government intervention in the economy in general. In particular, we run regressions on six different questions:

1. Government responsibility: The question asks the respondent, "How would you place your views on this scale? 1 means you agree completely with the statement on the left; 10 means you agree completely with the statement on the right; and if your views fall somewhere in between, you can choose any number in between. People should take more responsibility to provide for themselves (1) vs. The government should take more responsibility to ensure that everyone is provided for (10)?”

2. Income equality: The question asks the respondent to rate his or her views on a scale from 1 to 10 on the following statement: "Income should be made more equal" (1) versus "We need larger income differences as incentives" (10).

3. Private-state ownership: The question asks the respondent to place his/her views on a scale from 1 to 10 on the following statement: "Private ownership of business should be increased" (1), versus “Government ownership of business should be increased” (10).

\footnotetext{
data at the regional level for each year. The results of the regression when aggregating the data at the regional level at each point in time and the corresponding beta coefficients are reported in the appendix (Table A14 and Table A17, respectively.) From the analysis of the beta coefficients, it is indeed apparent that in aggregate the effect of growing up in a recession is relatively important compared to the other individual characteristics. For example, economic shocks have the same magnitude or even a larger effect than the percentage of African Americans in a region. The effect is also comparable to the impact of education (the effect however varies depending on the variable; for example, the effect is smaller for the variable help poor but larger for both the assistance poor and the work-luck variables; the impact of a macroeconomic shock is normally larger than education when we look at political behavior). Economic shocks have a larger effect than income when we look at political behavior; the effect is also sizeable when we look at preferences for redistribution.
} 
4. Society: egalitarian-competitive: the question asks the respondent, "And now, could you please tell me which type of society you think this country should aim to be in the future. For each pair of statements, would you prefer being closer to the first or to the second alternative? First statement: An egalitarian society where the gap between rich and poor is small, regardless of achievement. Second statement: A competitive society, where wealth is distributed according to one's achievement." The answer can take values from 1 to 5: First (1), Somewhat closer to first (2), Can't say (3), Somewhat closer to second (4), Second (5).

5. Society: welfare-low taxes. This question, like the one above, asks the respondent to identify a preference between two statements, on a scale of 1 to 5 . The first statement is: "A society with extensive social welfare, but high taxes." Second statement: “A society where taxes are low and individuals take responsibility for themselves."

6. Work-luck. The question asks the respondent to choose on a scale from 1 to 10 between the following two statements: "In the long run, hard work usually brings a better life" (1), "Hard work does not generally bring success-it is more a matter of luck and connections" (10).

The WVS also has two questions on political ideology and party affiliation: ${ }^{56}$

1. Political ideology: The question asks the respondent, "In political matters, people talk of 'the left' and 'the right.' How would you place your views on this scale, generally speaking?" The answer could range from "Left" (1) to "Right" (10).

2. Party affiliation. The question asks the respondent, "If there were a national election tomorrow, for which party on this list would you vote?" Each country in the survey has a country-specific list of political parties. We assign to each party a number summarizing their political ideology. Parties are coded on a scale from 1 to 10 (with 10 indicating a more left-wing ideology) using data from Huber et al. (1995).

We code all the questions such that a higher number is associated with more government intervention and more left-wing attitudes.

In the case of the cross-country analysis, we rely on the definition of economic shocks by Barro et al. (2008), ${ }^{57}$ who construct a measure of crises for a large set of countries starting from and improving Angus Maddison's dataset. The dataset includes time-series data on GDP from 1870 to today for a sample of 39 countries and estimates periods of economic disasters. They define trough-

\footnotetext{
56 The WVS does not contain questions on voting behavior in the most recent elections.

${ }^{57}$ All the details about the dataset constructed by Barro et al. (2008) are provided in the appendix.
} 
peak disaster periods as contractions in GDP growth of at least 10 percent. For each country, the authors provide the time interval of the economic disasters. For the OECD countries, most of the macroeconomic disasters took place before 1950 (with the exception of Finland), whereas nonOECD countries experienced macroeconomic disasters before and after $1950 .{ }^{58}$

Our macroeconomic shock variable is a dummy equal to 1 if the person experienced a macroeconomic disaster (following Barro's definition) during his or her impressionable years. Figure A2 shows our variable of interest by year of birth and for the 37 countries ${ }^{59}$ present in most of our regressions. The variable is a dummy for whether that specific cohort in one specific country had a macroeconomic disaster during their impressionable years. As is apparent from the figure, there is substantial variation in terms of exposure to different recession experiences. Latin American countries have many cohorts exposed to economic disasters. In the OECD countries, the oldest cohorts have typically been more exposed to economic disasters, but the extent of the exposure varies a lot among them.

In terms of individual controls, we follow closely the specification of the GSS and include in our regressions gender, employment and marital status, education, income, and religious denomination. Education is defined using a variable in the WVS that makes comparable the level of education across countries. Education is coded as low, medium, and upper. We also include in all our specifications ten income dummies. The WVS has a recoded version of income for all the countries, where each category includes an income decile. Dummies for religion include Roman Catholic, Protestant, Muslim, Orthodox and Other. The excluded group is given by nonreligious individuals. Unfortunately, the WVS does not contain any information on family background (such as family income when young or parental level of education) or race. We are therefore not able to include these controls in our analysis.

The basic specification is the following:

$$
\text { Beliefs }_{\text {ict }}=\alpha_{0}+\alpha_{1} \text { macro shock }_{\mathrm{c} \text {, imp.years }}+\alpha_{2} X_{i}+\beta_{a}+\delta_{c}+\eta_{t}+\delta_{c} * a g e+\varepsilon_{\text {ict }}
$$

where Beliefs $s_{i c t}$ indicates the response to one of the questions described above of individual $i$, interviewed at time $t$ in county $c$. The variable macro shock $k_{c \text {, imp.years }}$ is a dummy indicating whether the individual experienced a recession during the impressionable years in his or her country. We

\footnotetext{
${ }^{58}$ For example, in the United States, periods of economic disasters are 1906-1908, 1913-1914, 1918-1921, 1929-1933, and 1944-1947. In Argentina, periods of economic disasters are 1887-1891, 1895-1898, 1899-1900, 1901-1902, 19061907, 1912-1917, 1928-1932, 1958-1959, 1980-1982, 1987-1990, and 1998-2002. For the whole list of periods of economic disasters by country, see Barro et al. (2008).

${ }^{59}$ Malaysia and Sri-Lanka are not present in the WVS, although they are covered by Barro et al. (2008).
} 
drop immigrants from the analysis. $X_{i}$ are individual characteristics described above, $\beta_{a}, \delta_{c}$, and $\eta_{t}$ are age, country, and wave fixed effects; whereas $\delta_{c} *$ age includes country-specific age trends.

We present three different specifications. In the baseline specification, similar to the GSS specification, we control for age, gender, marital and labor market status, income, education, religion, and country and wave fixed effects. The baseline specification is reported in Table 5. (In Tables A18 and A19 of the appendix, we also report the specifications with cohort dummies, and cohort dummies and country-year interactions, respectively).

\subsection{Results}

The first six columns of Table 5 report the regressions for preferences for redistribution and government intervention. Individuals who experienced a macroeconomic disaster during the impressionable years prefer redistribution (a positive coefficient means a higher preference for government redistribution and government intervention in the economy). The coefficient on the variable indicating whether the person experienced a recession during her impressionable years is always significant at least at the 10 percent level in all specifications, including the two specifications with a smaller set of countries (columns 4 and 5). The AES estimates confirm the general finding found for each single variable and the significance level also increases to 1 percent. Consistent with the literature and with the findings for the United States, educated, married, male, and high-incomeearning individuals are less favorable to redistribution. ${ }^{60}$ Being unemployed increases the desire for government intervention in the economy.

To assess the magnitude of our results, we calculate the beta coefficients (they are reported in Table A26 of the appendix). A one-standard-deviation increase in our shock measure is associated with an increase of 0.01 standard deviations in preferences for redistribution $(0.03$ when we look at the society aimed at by individuals). The magnitude compared with other individual characteristics varies depending on the specification. For example, the impact of having experienced an economic shock when young is roughly equivalent to the effect of being unemployed when we look at the work-luck belief, 67 percent when we look at the income equality belief, but about 31 percent in the government responsibility regressions. The effect is between 12 percent and 20 percent of the effect of having a middle level of education and between 9 percent and 89 percent of the impact of an upper level of education (we only compare coefficients when the variables are significant).

\footnotetext{
${ }^{60}$ Being male is also negatively associated with the importance of luck as a driver of economic success. This result is different than what we found in the United States in the GSS, where there is a positive association between being male and the importance of luck as a driver of success (the result is also confirmed in the United States in the longitudinal analysis. See Section 4, below).
} 
In columns 7 and 8, we report the results for political ideology and party affiliation. We do find a positive association between experiencing a macroeconomic disaster when young and both left-wing ideology and affiliation with a left-wing political party. The effect is significant at the 1 percent level for party affiliation and at the 10 percent level for political ideology. The AES estimates are significant at the 1 percent level. In terms of magnitude, the effects are also sizeable. The signs of the remaining coefficients are broadly consistent with the literature. Women tend to be more leftwing. Being unemployed is also associated with a more left-leaning orientation. Education, similarly to what we found in the United States, has a different effect on political ideology and party affiliation. More educated people espouse a left-leaning ideology. Education, on the other hand, is negatively associated with declaring the intention to vote for a left-wing party in the next election. ${ }^{61}$

The specification reported in Table A18 and A19, which also includes cohort dummies and country and year-of-interview interactions, broadly confirms our findings. Two of the variables are less precisely estimated, but the AES effects are identical to the baseline specification.

We also run regressions with the WVS for other age ranges. ${ }^{62}$ The results are in line with what we found in the GSS. There is some evidence that, at least for political behavior, the period between ages 26 and 33 is relevant for the formation of political beliefs. But there is no systematic effect of macroeconomic shocks on preferences for redistribution or political behavior during other periods of life.

Similarly, with our analysis for the GSS, we also test the robustness of our results to the inclusion of other time-varying country characteristics during the impressionable years. In addition, we run a placebo assigning to each individual the macroeconomic shock of another country, and one showing that beliefs not related to the economy are not affected by economic shocks. ${ }^{63}$

The richer set of questions contained in the WVS allows an analysis of various beliefs. According to the theoretical literature on beliefs (Benabou and Tirole, 2006), another important value that could determine preferences for redistribution is the "belief in a just world" (the authors propose a feedback effect as in Piketty, 1995). The WVS has a question that asks the respondent,

\footnotetext{
${ }^{61}$ The discrepancy could be due to a different position on social and economic issues. We found similar results in the United States, where education was positively associated with belonging to the Republican Party but negatively associated with individuals declaring themselves as conservative.

${ }^{62}$ The results are reported in Tables A20 and A21, without and with the inclusion of the economic shock during the impressionable years, respectively.

${ }^{63}$ The results are reported in Tables A22-A24. For another country control, we include the average per capita GDP growth, as in the GSS. We also include a measure of democratization, as summarized by the polity2 index, a variable proxying for the level of democracy in a country and going from -10 (autocracy) to 10 (democracy). Variables on educational policies, wage inequality, and crime are not available on a yearly basis for our countries and period of analysis. As a belief unrelated to macroeconomic conditions, we use a $0-1$ question, asking the respondent whether he or she believes in heaven.
} 
"Why are there people in this country who live in need? Here are four possible reasons. Which one reason do you consider to be most important?" The respondent could choose between unlucky, laziness or lack of willpower, injustice in society, modern progress. We create a variable equal to 1 if the person answers "injustice in society."

Cogley and Sargent (2008) argue that recessions create a belief of pessimism that is hard to eradicate. The closest question in the dataset is one that asks the respondents how much choice and control they have over their lives. The question is phrased as follows: "Some people feel they have completely free choice and control over their lives, while other people feel that what they do has no real effect on what happens to them. Please use this scale where 1 means 'none at all' and 10 means 'a great deal' to indicate how much freedom of choice and control you feel you have over the way your life turns out." We do find that recessions have an impact on beliefs in a just world and pessimism. The sense of injustice and pessimism created from recessions could also help to explain why people become more favorable to government intervention. The results for these two variables are reported in Table A25 of the Appendix. ${ }^{64}$

\section{Evidence from the National Longitudinal Survey of the High School Class of 1972}

Our third dataset is the National Longitudinal Survey of the High School Class of 1972 (NLS72). The NLS72 dataset provides a nationally representative sample of the high school population for the class of 1972. Since the sample contains only one birth cohort, with most students being born in 1954 or 1955, there is no need to correct for potential cohort or life-cycle effects. The survey provides a broad spectrum of information on socioeconomic status, home background, educational attainment, work status, religion, marriage, and the family. For our purposes, the survey also contains data on the belief about the relative importance of work versus luck as a driver of success at the time of original interview and in subsequent years. Data was collected during six years: 1972, 1973, 1974, 1976, 1979, and 1986. Data collected in the base year (1972) contains information on students' personal and family background. Follow-ups, conducted in 1973, 1974, 1976, 1979, and 1986, offer information on work, family, educational experience, and opinions since high school. We use the panel dimension of the survey from 1973 to 1986 and merge it with students' personal and family background obtained from the base year.

${ }^{64}$ The results are robust to the three different specifications, and AES estimates are also very strong. 
Despite the limitation of not having the cohort variation, this dataset has the advantage of following respondents over time, including information on locations at the state level. We use the restricted geocode version of the survey to know an individual's location in each survey year. This allows us to associate to each individual the unemployment rate of his or her state of residence at each point in time. ${ }^{65}$

The appendix has more details about the data construction but we briefly describe our variables of interest here. Our dependent variable is a question asking the respondent whether he or she thinks that luck is more important than hard work as a determinant of economic success. The answers can take the values 1 (strongly disagree), 2 (disagree), 3 (agree), or 4 (strongly agree).

As an indicator of local economic conditions, we use the unemployment rate of the state in which an individual resided in each survey year. The data on state unemployment come from the BLS. There is substantial variation in the state unemployment rates from 1972 to 1986, the period in which people were interviewed, making this a useful measure for our purposes. We also use another measure of recession based on the state GDP for comparison with the other parts of the paper.

We include two sets of controls: the first set is time-variant and includes labor market and marital status (a dummy for being unemployed and a dummy for being married, respectively), a dummy for when the individual completed college and the log of real personal income. We also include a set of personal characteristics that do not vary over time (the information was collected in 1972): a dummy if the person is African American, a dummy for being male, a variable indicating the level of education of the father (a dummy if the father didn't complete high school), the religion in which the person was raised ${ }^{66}$ and the real $\log$ of family income. The survey also collected information on grades during high school, whether the person was in an academic track, and whether he or she was working part time during high school. ${ }^{67}$ Descriptive statistics for all our variables are provided in Table A1 of the appendix.

Given the panel structure of the survey and the particular age period in which individuals are followed, we implement a different empirical strategy than the one used for the GSS and the WVS. We analyze the formation of beliefs as a function of current economic conditions. Since individuals are interviewed during the impressionable years and when they are 32, we would like to compare the

\footnotetext{
65 The number of valid observations per year is described in the appendix. Sample attrition in the survey is not systematic. One potential problem could be that more entrepreneurial subjects are more likely to leave their state of residence during a recession. This could increase the probability that they will drop out from the sample. We do not believe this type of attrition is a concern, since the numbers of movers is similar to people with similar characteristics in datasets such as the Current Population Survey.

${ }^{66}$ We include five dummies for religious denomination: Protestant, Roman Catholic, Other Christian, Jewish, and Other. The excluded group is given by nonreligious individuals.

${ }^{67}$ Details on the construction of the variables and the exact coding of the questions are provided in the appendix.
} 
impact of the state unemployment rate during the impressionable years and when the person was 32 . The panel structure also allows us to look at the interaction effects between the unemployment rate during the impressionable years and personal experiences during that period, since we know the exact location of the individual at each point in time.

For an individual $i$, living in state $s$ and interviewed at time $t$, we estimate the following equation:

$$
\text { belief }_{\text {ist }}=\alpha+\beta_{0} u n_{s, 18-25}+\beta_{1} u n_{s, 32}+\gamma_{0} X_{i t}+\gamma_{1} Z_{i}+\delta_{s}+\eta_{t}+\varepsilon_{i s t}
$$

where we split the effect of the state unemployment rate into two parts: $u n_{i s, 18-25}$ is the state unemployment rate times a dummy equal to 1 if the survey year is between 1972 and 1979 (in those years, the individual is between 18 and 25) and zero otherwise; similarly, $u n_{i s, 32}$ is the state unemployment rate times a dummy equal to 1 if the survey year is 1986 (when the respondents are 32) and zero otherwise. $X_{i t}$ and $Z_{i}$ are the time-varying and time-invariant controls described above. All regressions include state and year fixed effects. The error terms are clustered by state. ${ }^{68}$ The relevant coefficients for our purposes are $\beta_{0}$ and $\beta_{1}$.

One problem with the empirical approach followed using the panel structure is that we are looking at the contemporaneous effect of local economic conditions on beliefs; therefore, the issue of reverse causality is more relevant than when the analysis is done retrospectively, as in the GSS or the WVS. Another way of using the NLS72 would be to look at the cross-section of individuals interviewed in 1986 and assign to each of them the average local unemployment rate of the states where they lived between 18 and 25. This strategy would be exactly equal to what we did with the GSS, but looking at only one cohort. Indeed, in a regression on the cross-section of individuals interviewed in 1986, the average unemployment rate of the states where individuals lived during the impressionable years has a coefficient of 0.012 and is significant at the 10 percent level, whereas the coefficient of the state unemployment rate in 1986 is -0.002 and is not statistically significant. ${ }^{69}$ The results are in line with what we found in the GSS and the WVS.

\subsection{Results}

Table 6 addresses the effect of local macroeconomic conditions during the impressionable years and later on in life. Column 1 presents the results using the state unemployment rate, whereas column 2 uses a dummy indicating a state recession. The unemployment rate during the impressionable years has a strong effect on the belief that luck is an important driver of economic

\footnotetext{
${ }^{68}$ We present the results clustered by state. Another option would be to cluster by individual, since there could be correlations across observations of the same person. Results are very similar when the errors are clustered in this way. ${ }_{69}$ There are only 3,311 respondents that have no missing observations for the whole survey period.
} 
success, whereas unemployment in 1986 (when the respondents are 32) is not significant. Controls have the expected effect: African Americans tend to believe more in the importance of luck as a driver of success, as do men overall. Being unemployed also plays an important role. On the other hand, a higher personal income and being married reduce the importance of luck as a driver of success. Among the personal characteristics, income of the family when young plays an important role, whereas the education of the father is not relevant. High school students who were in an academic track and had higher grades are less likely to report that luck is more important than effort, together with those who were working part time when in high school. People belonging to any religious denomination believe that effort is more relevant than luck for economic success. Overall the picture seems to be fairly consistent with the results found in the GSS. An analysis of the beta coefficients (reported in Table A27 of the appendix) shows that for the cohort of individuals who finished high school in 1972 the state unemployment rate is as important as race in the determination of work versus luck as a driver of success. The magnitude also appears to be larger than unemployment status. Interestingly, the state unemployment rate appears to be a more important measure of the severity of economic conditions when compared with the recession dummy (the beta coefficient is almost twice as big).

As we did with the General Social Survey, we split the sample between people who moved between states during the impressionable years and people who did not. ${ }^{70}$ The results for people who did not move are slightly stronger and in line with what we found in the GSS (Table A27). We also run a specification where we control for the other time-variant characteristics (including crime, quality of education, wage inequality, and home ownership) and run a placebo assigning to each individual a different state of residence (Tables A28 and A29). All our results survive to the various robustness checks.

The focus of this section has been an analysis of the generation who finished high school in 1972. The NLS72 is an important complement to our study because individuals can be observed during their impressionable years and then eight years later. In addition, a wealth of information exists on personal background and personal experiences during the impressionable years. However, in the NLS72, we are restricted to one specific cohort. We take the NLS72 exercise as complementary evidence to our other datasets. The results are larger overall than the GSS; this could

\footnotetext{
${ }^{70}$ Roughly 30 percent of our sample moved to a different state at least once between 18 and 25 . The average is slightly higher than in the GSS. This is partly due to the fact that the NLS72 uses states and not regions as geographical units; therefore, people moving between states but within the same region are considered movers in the NLS72 but stayers in the GSS. Also the sample of the NLS72 is selected in the sense that includes people who finished high school who are typically more mobile than people who drop out of high school.
} 
be due to a variety of reasons: there is more measurement error in the GSS since individuals cannot be followed over time; in the GSS, the shock is identified at the regional level, not at the state level; the recession of 1979 could have had particularly strong effects on young adults. The result could also be larger in the NLS72 because we study the impact of the contemporaneous effect of the recession during the impressionable years (from the GSS, we know that the effect tends to fade with age). Nevertheless, the NLS72 supports a robust finding that confirms what we found for regional shocks in the United States and for national shocks in a large set of countries: experiencing a recession when young has a permanent effect on the formation of preferences for redistribution.

\section{Heterogeneous effects}

The analysis so far has considered that all individuals respond in the same way to recessions during their impressionable years. However, the effect of a recession on beliefs could depend on initial conditions during early adulthood, including income and education level of the parents, or performance in high school. In addition, personal experiences during the impressionable years, including marital or employment status or level of income, can also affect the formation of beliefs.

In order to test for this possibility, we include in our specification interaction terms between recessions during the impressionable years and different initial characteristics or different experiences during the impressionable years. The NLS72 is the most appropriate among our datasets because we can observe individuals at each point in time during the impressionable years.

We present the results in two tables: in Tables 7 and 8, we interact the state unemployment rate during the impressionable years with time-invariant and time-varying controls, respectively. Among the time-invariant controls, being Jewish, having gone through an academic track, and having higher grades in high school reduces the impact of experiencing a recession when young in the formation of beliefs. The other interaction terms with time-invariant controls are never significant, and overall our main results on beliefs hold. With respect to the time-varying controls: having a college degree or having a higher income during the impressionable years reduces the emphasis on luck as a driver of economic success. For people who completed college and had a higher income during the impressionable years, the impact of recessions on beliefs is slightly lower. The interactions with other experiences during a recession do not give significant results.

We also check for the presence of heterogeneous effects using the other two datasets. ${ }^{71}$ In the WVS, we find some effect of heterogeneity when we look at the interaction with income and

\footnotetext{
71 The results are available from the authors.
} 
education. The effects are similar to what we found in the $\mathrm{NLS}_{2} 2^{72}$; in addition, the impact of experiencing a macroeconomic shock fades with age, but only for some of the variables on preferences for redistribution and government intervention. Independently of the interaction effects, the overall impact of recession on preferences for redistribution, government intervention, and political behavior remains positive and significant. When using the GSS, we found some heterogeneity with income, education, and race $^{73}$; on the other hand, we do not find any heterogeneity with respect to the income of the family at age 16, father's education, or gender.

Overall, we find that the effect of experiencing a recession when young is quite general and persistent, with slightly stronger effects for people who suffered more during periods of hardship.

\section{Conclusions}

This paper shows that large macroeconomic shocks experienced during the critical years of early adulthood shape preferences for redistribution. Individuals who grew up during a recession tend to support more government redistribution and believe that luck is more relevant than effort in determining economic success in life. Our findings are supported using evidence from three different datasets, and are robust to the inclusion of a rich set of controls and various specifications. Our results also show that macroeconomic shocks have an impact on actual behavior, such as voting: the effect of having individuals living through a recession when young could explain in some years up to 15 percent of the probability of voting for a Democratic presidential candidate in some U.S. regions.

This paper provides empirical evidence on the nature of preferences for redistribution, linking economics to important findings from social psychology. It contributes to the literature that claims that important historical experiences are relevant in shaping economic outcomes and provides empirical grounds for the models that endogenize political preferences and beliefs.

Our results suggest that the effect is not driven by differences in endowment or other timevarying regional characteristics, but further research and the availability of longer panel datasets on preferences for redistribution are needed to better pin down the mechanisms driving the results.

\footnotetext{
${ }^{72}$ The interaction effect with education is always negative but significant (at the 1 percent level) 50 percent of the time (for party affiliation and three of the measures on preferences for redistribution). Similar results are found when we interact our measure of macroeconomic shock with income: the interaction is always negative but significant for two of the measures for preferences for redistribution and for party affiliation. There are no heterogeneous effects by gender.

${ }^{73}$ For education, we find a negative interaction only for party affiliation and voting behavior; whereas income has a negative interaction only with the variables help poor and work-luck. We find an effect of an interaction with being black for the variable indicating political ideology and for the preference for redistribution variable belp poor.
} 


\section{References}

Alesina, A., and G.M. Angeletos, 2005, "Fairness and Redistribution: US vs. Europe," American Economic Review, Vol. 95, pp. 913-935.

Alesina, A., and N. Fuchs-Schündeln, 2008, "Good Bye Lenin (or Not?)—The Effect of Communism on People's Preferences," American Economic Review, Vol. 97, pp. 1507-1528.

Alesina, A., and P. Giuliano, 2011, "Preferences for Redistribution," in Handbook of Social Economics, Vol. 1A, Jess Benhabib, Matthew O. Jackson, and Alberto Bisin (eds.), pp. 93-131; The Netherlands: North-Holland.

Alesina, A., and E. Glaeser, 2004, Fighting Poverty in the US and Europe: A World of Difference, Oxford, Oxford University Press.

Alesina, A., and E. La Ferrara, 2005, "Ethnic Diversity and Economic Performance," Journal of Economic Literature, Vol. 43, pp. 721-761.

Barro, R., and J. Ursua, 2008, "Macroeconomic Crises since 1870," Brookings Paper on Economic Activity, Vol. 39 (1), pp. 255-350.

Benabou, R., and J. Tirole, 2006, "Belief in a Just World and Redistributive Politics," Quarterly Journal of Economics, Vol. 121 (2), pp. 699-746.

Ben-Porath, Y., 1973, "Short-Term Fluctuations in Fertility and Economic Activity in Israel," Demography, X, pp. 185-204.

Boustan, L., F. Ferreira, H. Winkler, and E. Zolt, "The Effect of Rising Income Inequality on Taxation and Public Expenditures: Evidence from U.S. Municipalities and School Districts, 1970-2000," Review of Economics and Statistics, forthcoming.

Brim, O. G., and J. Kagan, 1980, Constancy and Change in Human Development, Cambridge, MA: Harvard University Press.

Cameron, A. C., J. B. Gelbach, and D. Miller, 2008, "Bootstrap-Based Improvements for Inference with Clustered Errors," The Review of Economics and Statistics, Vol. 90 (3), pp. 414-427.

Card, D., and A. Krueger, 1992, "Does School Quality Matter? Returns to Education and the Characteristics of Public Schools in the United States," Journal of Political Economy, Vol. 100 (1), pp. 1-40.

Cascio, E. U., and S. Reber, 2013, "The Poverty Gap in School Spending Following the Introduction of Title I," American Economic Review, Vol. 103 (3): pp. 423-427.

Clingingsmith, D., A. Khwaja, and M. Kremer, 2009, "Estimating the Impact of the Hajj: Religion and Tolerance in Islam's Global Gathering," Quarterly Journal of Economics, Vol. 124 (3), pp. $1133-1170$. 
Cogley, T., and T. Sargent, 2008, “The Market Price of Risk and the Equity Premium: a Legacy of the Great Depression," Journal of Monetary Economics, Vol.55, pp. 454-476.

Corcoran, S. P., and W. N. Evans, 2010, "Income Inequality, the Median Voter, and the Support for Public Education, NBER WP 16097.

Corneo, G., and H.P. Grüner, 2002, "Individual Preferences for Political Redistribution,” Journal of Public Economics, Vol. 83, pp. 83-107.

Cutler, N.E., 1974, "Aging and Generations in Politics: The Conflict of Explanations and Inference," in Public Opinion and Political Attitudes, A. R. Wilcox (ed.), pp. 440-462; New York: Wiley.

Dehejia, R., and A. L. Muney, 2004, "Booms, Busts, and Babies' Health," The Quarterly Journal of Economics, Vol. 119 (3), pp. 1091-1130.

Dennis, J., 1973, Socialization in Politics: A Reader. New York: Wiley.

Di Tella, R., J. Donna, and R. MacCulloch, 2007, "Oil, Macro Volatility, and Crime in the Determination of Beliefs in Venezuela," in Venequela: Anatomy of a Collapse, Hausmann, R., and F. Rodriguez (eds.).

Di Tella, R., J. Donna, and R. MacCulloch, 2008, "Crime and Beliefs: Evidence from Latin America," Economic Letters, Vol. 99, pp. 566-569.

Di Tella, R., J. Dubra, and R. MacCulloch, 2010, "A Resource Belief-Curse? Oil and Individualism," in The Natural Resources Trap: Private Investment Without Public Commitment, Hogan, W., and F. Sturzenegger (eds.). MIT Press, Cambridge, Mass.

Di Tella, R., S. F. Galiani, and E. S. Schargrodsky, 2007, "The Formation of Beliefs: Evidence from the Allocation of Land Titles to Squatters," Quarterly Journal of Economics, Vol. 122 (1), 209241.

Easton, D., and J. Dennis, 1969, Children in the Political System: Origins of Political Legitimacy. New York: McGraw-Hill.

Friedman, M., and A. Schwartz, 1963, A Monetary History of the United States, 1867-1960, Princeton, NJ, Princeton University Press.

Glenn, N.D., 1980, "Values, Attitudes and Beliefs," in Constancy and Change in Human Development, O.G. Brim and J. Kagan (eds.). Cambridge, Mass.: Harvard University Press.

Goldin, C., and L. F. Katz (2008), The Race Between Education and Technology. Cambridge, Mass.: Harvard University Press.

Graham, J. R., and K. Narasimhan, 2004, "Corporate Survival and Managerial Experiences During the Great Depression," manuscript, Duke University.

Greenstein, F. I., 1965, Children and Politics. New Haven, Conn.: Yale University Press. 
Greenwood, R., and S. Nagel, 2009, "Inexperienced Investors and Bubbles," Journal of Financial Economics, Vol. 93 (2), pp. 239-258.

Hess, R. D., and J. V. Torney, 1967, The Development of Political Attitudes in Children. Chicago: Aldine.

Huber, J., and R. Inglehart, 1995, "Expert Interpretations of Party Space and Party Locations in 42 Societies," Party Politics, Vol. 1, pp. 73-111.

Kahn, L., 2010, “The Long-Term Labor Market Consequences of Graduating from College in a Bad Economy," Labour Economics, Vol. 17 (2).

Kling, J., J. Liebman, L. Katz, and L. Sabonmatsu, "Moving to Opportunity and Tranquility: Neighborhood Effects on Adult Economic Self-Sufficiency and Health from a Randomized Housing Voucher Experiment,” 2004, mimeograph, Harvard University.

Krosnick, J. A., and D. F. Alwin, 1989, "Aging and Susceptibility to Attitude Change," Journal of Personality and Social Psychology, Vol. 57, pp. 416-425.

Luttmer, E., 2001, “Group Loyalty and the Taste for Redistribution,” Journal of Political Economy, Vol. 109 (3), pp. 500-528.

Luttmer, E., and M. Singhal, 2011, "Culture, Context, and the Taste for Redistribution," American Economic Journal: Economic Policy, Vol. 3, pp. 157-179.

Malmendier, U., and S. Nagel, 2011, "Depression Babies: Do Macroeconomic Experiences Affect Risk-Taking," Quarterly Journal of Economics, Vol. 126 (1), pp. 373-416.

Malmendier, U., and S. Nagel, 2013, "Learning from Inflation Experiences", mimeo, University of California, Berkeley.

Mannheim, K., 1952, "The Problem of Generations," in Essays on the Sociology of Knowledge, P. Kecskemeti (ed.). London: Routledge \& Kegan Paul.

Marx, K., 1867, Capital: A Critique of Political Economy (Das Kapital). Penguin Classics.

Newcomb, T.M., K. E. Koenig, R. Flack, and D. Warwick, 1967, Persistence and Change: Bennington College and Its Students After 25 years. New York: Wiley.

Oreopoulos, P., T. Von Wachter, and A. Heisz, 2012, "The Short- and Long-Term Career Effects of Graduating in a Recession: Hysteresis and Heterogeneity in the Market for College Graduates," American Economic Journal: Applied Economics, Vol. 4(1), pp. 1-29.

Piketty, T., 1995, "Social Mobility and Redistributive Policies," Quarterly Journal of Economics, Vol. 110 (3), pp. 551-584.

Ravallion, M., and M. Loskin, 2000, "Who Wants to Redistribute? The Tunnel Effect in 1990 Russia," Journal of Public Economics, Vol. 76 (1), pp. 87-104. 
Ruhm, C., 2000, “Are Recessions Good for Your Health?” Quarterly Journal of Economics, 115 (2), pp. 617-650.

Sears, D. O., 1975, "Political Socialization" in Handbook of Political Science, Greenstein, F. I., and N. W. Polsby (eds.). Reading, Mass: Addison-Wesley.

Sears, D. O., 1981, "Life Stage Effects on Attitude Change, Especially Among the Elderly," in Aging: Social Change, Kiesler, S. B., J. N. Morgan, and V. K. Oppenheim (eds.), pp. 183-204. New York: Academic Press.

Sears, D. O., 1983, "The Persistence of Early Political Predispositions: The Role of Attitude Object and Life Stage," Review of Personality and Social Psychology, Vol. 4, pp. 79-116.

Spear, L. P., 2000, "Neurobehavioral Changes in Adolescence," Current Directions in Psychological Science, Vol. 9 (4), pp. 111-114.

Vissing-Jorgensen, A., 2002, "Towards an Explanation of Household Portfolio Choice Heterogeneity: Nonfinancial Income and Participation Cost Structure," working paper, Northwestern University. 


\section{Figure 1 \\ The effect of "growing up in a recession" on "voting democrat" by region}

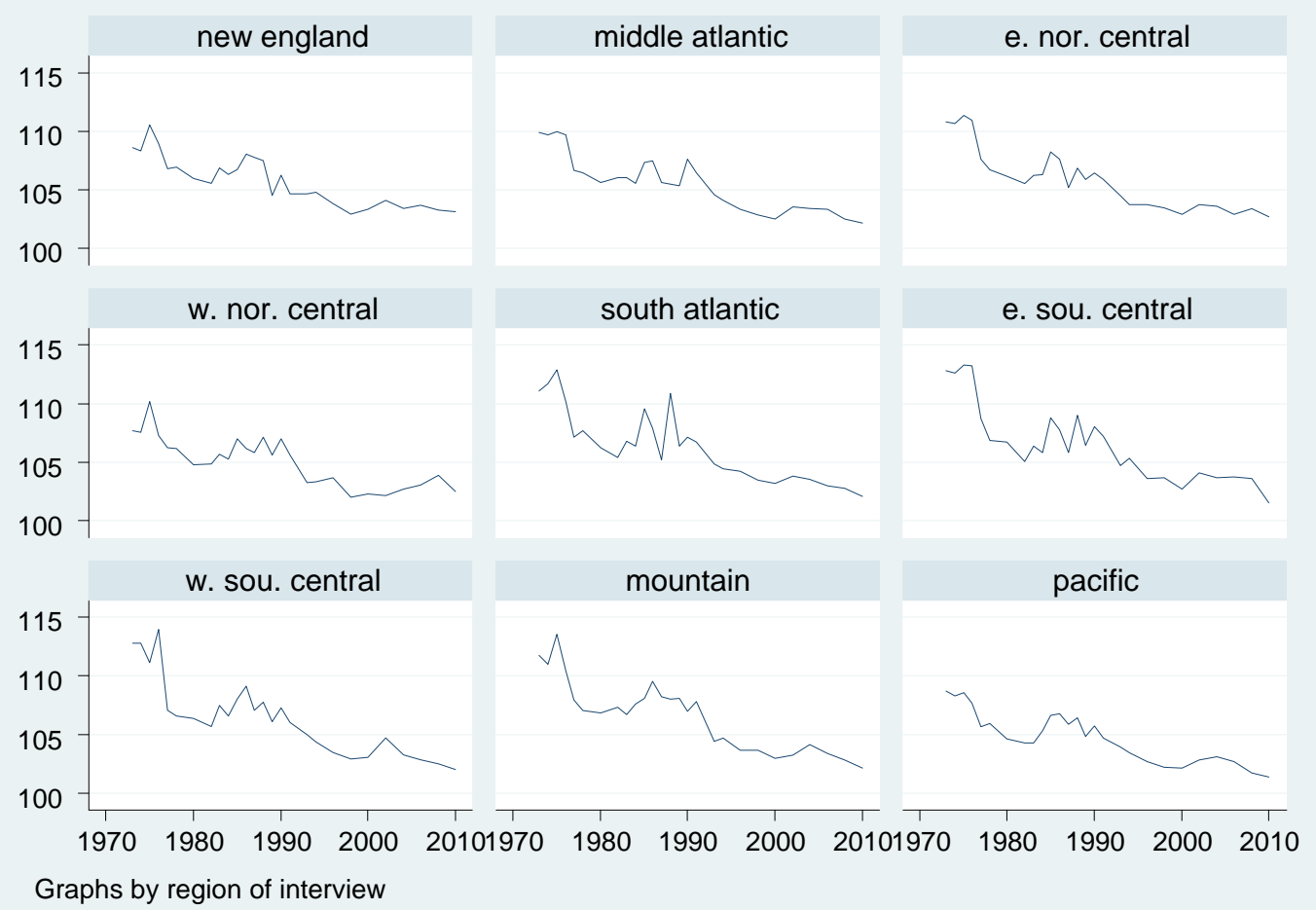

For each region, we plot the ratio of the fitted "voting democrat" outcome (from column (6) of Table 2) to the counterfactual "voting democrat" outcome obtained by setting the economic shock coefficient to zero in the same specification. The fitted-counterfactual has been multiplied by one hundred to be expressed as a percentage. Deviations from a value of one hundred are attributable to the heterogeneous effects of having individuals experiencing a recession when young. Since we control for year of interview, age and cohort fixed effects, together with region of residence at 16 and region of interview fixed effects and individual controls, the difference between the fitted and counterfactual series can only identify the heterogeneous effects on voting for the democratic party of having different individuals with different macroeconomic experiences during young in each region. 
Table 1

GSS: Baseline Specification

\begin{tabular}{|c|c|c|c|c|c|c|c|c|c|}
\hline & $\begin{array}{c}(1) \\
\text { Help poor }\end{array}$ & $\begin{array}{c}(2) \\
\text { Assistance } \\
\text { poor }\end{array}$ & $\begin{array}{c}\text { (3) } \\
\text { Work-luck }\end{array}$ & $\begin{array}{c}\text { (4) } \\
\text { Party } \\
\text { affiliation }\end{array}$ & $\begin{array}{c}(5) \\
\text { Political } \\
\text { views }\end{array}$ & $\begin{array}{c}\text { (6) } \\
\text { Voting } \\
\text { democrat }\end{array}$ & $\begin{array}{c}\text { (7) } \\
\text { AES } \\
\text { Pref. } \\
\text { redistr. }\end{array}$ & $\begin{array}{c}\text { (8) } \\
\text { AES } \\
\text { Pol. } \\
\text { Behav. }\end{array}$ & $\begin{array}{c}(9) \\
\text { AES } \\
\text { All }\end{array}$ \\
\hline Economic shock & $\begin{array}{c}0.033^{* *} \\
(0.016)\end{array}$ & $\begin{array}{c}0.021 * * \\
(0.010)\end{array}$ & $\begin{array}{c}0.017 * * \\
(0.008)\end{array}$ & $\begin{array}{c}0.177 * * * \\
(0.029)\end{array}$ & $\begin{array}{c}0.133^{* * *} * \\
(0.022)\end{array}$ & $\begin{array}{c}0.043^{* * *} \\
(0.009)\end{array}$ & $\begin{array}{c}0.028 * * * \\
(0.011)\end{array}$ & $\begin{array}{c}0.091 * * * \\
(0.011)\end{array}$ & $\begin{array}{c}0.056 * * * \\
(0.010)\end{array}$ \\
\hline Years of education & $\begin{array}{c}-0.051 * * * \\
(0.006)\end{array}$ & $\begin{array}{c}-0.017 * * * \\
(0.002)\end{array}$ & $\begin{array}{c}0.006 * * * \\
(0.002)\end{array}$ & $\begin{array}{c}-0.033 * * * \\
(0.008)\end{array}$ & $\begin{array}{c}0.020 * * * \\
(0.007)\end{array}$ & $\begin{array}{c}0.001 \\
(0.002)\end{array}$ & & & \\
\hline Married & $\begin{array}{c}-0.139 * * * \\
(0.016)\end{array}$ & $\begin{array}{c}-0.036 * * * \\
(0.009)\end{array}$ & $\begin{array}{c}-0.059 * * * \\
(0.008)\end{array}$ & $\begin{array}{c}-0.220 * * * \\
(0.036)\end{array}$ & $\begin{array}{c}-0.264 * * * \\
(0.014)\end{array}$ & $\begin{array}{c}-0.058 * * * \\
(0.008)\end{array}$ & & & \\
\hline Female & $\begin{array}{c}0.164 * * * \\
(0.017)\end{array}$ & $\begin{array}{c}0.060 * * * \\
(0.011)\end{array}$ & $\begin{array}{c}-0.075^{* * *} \\
(0.012)\end{array}$ & $\begin{array}{c}0.178^{* * *} \\
(0.035)\end{array}$ & $\begin{array}{c}0.088^{* * *} \\
(0.019)\end{array}$ & $\begin{array}{c}0.037^{* * *} \\
(0.008)\end{array}$ & & & \\
\hline Black & $\begin{array}{c}0.635^{* * *} \\
(0.036)\end{array}$ & $\begin{array}{c}0.276^{* * *} \\
(0.012)\end{array}$ & $\begin{array}{c}0.107 * * * \\
(0.010)\end{array}$ & $\begin{array}{c}1.468^{* * *} \\
(0.064)\end{array}$ & $\begin{array}{c}0.296^{* * *} \\
(0.021)\end{array}$ & $\begin{array}{c}0.449 * * * \\
(0.016)\end{array}$ & & & \\
\hline Unemployed & $\begin{array}{c}0.118^{* * *} \\
(0.036)\end{array}$ & $\begin{array}{c}0.066^{* * *} \\
(0.016)\end{array}$ & $\begin{array}{c}0.058 * * * \\
(0.005)\end{array}$ & $\begin{array}{c}0.113^{* * *} \\
(0.040)\end{array}$ & $\begin{array}{c}0.100 * * \\
(0.045)\end{array}$ & $\begin{array}{c}0.050^{* * *} \\
(0.014)\end{array}$ & & & \\
\hline Income fixed effects & yes & yes & yes & yes & yes & yes & yes & yes & yes \\
\hline Age fixed effects & yes & yes & yes & yes & yes & yes & yes & yes & yes \\
\hline Year fixed effects & yes & yes & yes & yes & yes & yes & yes & yes & yes \\
\hline Region interview f.e. & yes & yes & yes & yes & yes & yes & yes & yes & yes \\
\hline Region at 16 f.e. & yes & yes & yes & yes & yes & yes & yes & yes & yes \\
\hline (Region at 16)*age & yes & yes & yes & yes & yes & yes & yes & yes & yes \\
\hline Observations & 24287 & 15416 & 30694 & 43443 & 38525 & 27267 & 23466 & 36412 & 29939 \\
\hline R-squared & 0.09 & 0.07 & 0.02 & 0.11 & 0.05 & 0.15 & & & \\
\hline
\end{tabular}

Notes: [1] Standard errors are clustered at the region at 16 level, and estimated using the wild bootstrap method; $*$ significant at $10 \%, * *$ significant at $5 \%$, *** significant at $1 \%$; [2] the number of observations reported for the AES in columns 7, 8 and 9 is the average number of observations in the regressions for the measures of preferences for redistribution, political behavior, or all of them respectively. 
Table 2

GSS: Specification with Cohort Effects

\begin{tabular}{|c|c|c|c|c|c|c|c|c|c|}
\hline & $\begin{array}{c}(1) \\
\text { Help poor }\end{array}$ & $\begin{array}{c}\text { (2) } \\
\text { Assistance } \\
\text { poor }\end{array}$ & $\begin{array}{c}\text { (3) } \\
\text { Work-luck }\end{array}$ & $\begin{array}{c}\text { (4) } \\
\text { Party } \\
\text { affiliation }\end{array}$ & $\begin{array}{c}\text { (5) } \\
\text { Political } \\
\text { views }\end{array}$ & $\begin{array}{c}(6) \\
\text { Voting democrat }\end{array}$ & $\begin{array}{c}(7) \\
\text { AES } \\
\text { Pref. } \\
\text { redistr. }\end{array}$ & $\begin{array}{c}\text { (8) } \\
\text { AES } \\
\text { Pol. } \\
\text { behav. }\end{array}$ & $\begin{array}{c}(9) \\
\text { AES } \\
\text { All }\end{array}$ \\
\hline Economic shock & $\begin{array}{c}0.037 * * \\
(0.016)\end{array}$ & $\begin{array}{l}0.023^{*} \\
(0.012)\end{array}$ & $\begin{array}{l}0.017 * \\
(0.009)\end{array}$ & $\begin{array}{c}0.180^{* * *} \\
(0.034)\end{array}$ & $\begin{array}{c}0.136^{* * *} \\
(0.029)\end{array}$ & $\begin{array}{c}0.044 * * * \\
(0.010)\end{array}$ & $\begin{array}{c}0.033 * * * \\
(0.010)\end{array}$ & $\begin{array}{c}0.093^{* * * *} \\
(0.013)\end{array}$ & $\begin{array}{c}0.059 * * * \\
(0.010)\end{array}$ \\
\hline Years educ. & $\begin{array}{c}-0.051^{* * *} \\
(0.006)\end{array}$ & $\begin{array}{c}-0.018^{* * *} \\
(0.002)\end{array}$ & $\begin{array}{c}0.006 * * * \\
(0.002)\end{array}$ & $\begin{array}{c}-0.033 * * * \\
(0.008)\end{array}$ & $\begin{array}{c}0.020^{* * *} \\
(0.008)\end{array}$ & $\begin{array}{c}0.001 \\
(0.002)\end{array}$ & & & \\
\hline Married & $\begin{array}{c}-0.138^{* * *} \\
(0.015)\end{array}$ & $\begin{array}{c}-0.036 * * * \\
(0.009)\end{array}$ & $\begin{array}{c}-0.060^{* * *} \\
(0.008)\end{array}$ & $\begin{array}{c}-0.219 * * * \\
(0.036)\end{array}$ & $\begin{array}{c}-0.264 * * * \\
(0.014)\end{array}$ & $\begin{array}{c}-0.058^{* * *} \\
(0.008)\end{array}$ & & & \\
\hline Female & $\begin{array}{c}0.163^{* * *} \\
(0.017)\end{array}$ & $\begin{array}{c}0.060 * * * \\
(0.011)\end{array}$ & $\begin{array}{c}-0.075^{* * *} \\
(0.012)\end{array}$ & $\begin{array}{c}0.178^{* * *} \\
(0.036)\end{array}$ & $\begin{array}{c}0.088^{* * *} \\
(0.019)\end{array}$ & $\begin{array}{c}0.037 * * * \\
(0.008)\end{array}$ & & & \\
\hline Black & $\begin{array}{c}0.635^{* * *} \\
(0.036)\end{array}$ & $\begin{array}{c}0.276 * * * \\
(0.012)\end{array}$ & $\begin{array}{c}0.107 * * * \\
(0.010)\end{array}$ & $\begin{array}{c}1.469 * * * \\
(0.064)\end{array}$ & $\begin{array}{c}0.296^{* * *} \\
(0.021)\end{array}$ & $\begin{array}{c}0.449 * * * \\
(0.016)\end{array}$ & & & \\
\hline Unemployed & $\begin{array}{c}0.117 * * * \\
(0.036)\end{array}$ & $\begin{array}{c}0.066^{* * *} \\
(0.016)\end{array}$ & $\begin{array}{c}0.058^{* * *} \\
(0.005)\end{array}$ & $\begin{array}{c}0.116^{* * *} \\
(0.041)\end{array}$ & $\begin{array}{c}0.099 * * \\
(0.045)\end{array}$ & $\begin{array}{c}0.051 * * * \\
(0.014)\end{array}$ & & & \\
\hline Income fixed effects & yes & yes & yes & yes & yes & yes & yes & yes & yes \\
\hline Age fixed effects & yes & yes & yes & yes & yes & yes & yes & yes & yes \\
\hline Year fixed effects & yes & yes & yes & yes & yes & yes & yes & yes & yes \\
\hline Cohort fixed effects & yes & yes & yes & yes & yes & yes & yes & yes & yes \\
\hline Region interview f.e. & yes & yes & yes & yes & yes & yes & yes & yes & yes \\
\hline Region at 16 f.e. & yes & yes & yes & yes & yes & yes & yes & yes & yes \\
\hline (Region at 16)*age & yes & yes & yes & yes & yes & yes & yes & yes & yes \\
\hline Observations & 24287 & 15416 & 30694 & 43443 & 38525 & 27267 & 23466 & 36412 & 29939 \\
\hline R-squared & 0.09 & 0.07 & 0.02 & 0.11 & 0.05 & 0.15 & & & \\
\hline
\end{tabular}

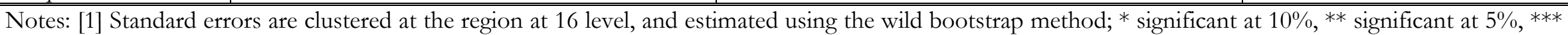

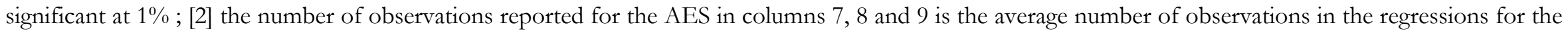
measures of preferences for redistribution, political behavior, or all of them respectively. 
Table 3

GSS: Specification with Cohort effects, Region-Years Interactions and Additional Controls

\begin{tabular}{|c|c|c|c|c|c|c|c|c|c|}
\hline & $\begin{array}{c}(1) \\
\text { Help poor }\end{array}$ & $\begin{array}{c}(2) \\
\text { Assistance } \\
\text { poor }\end{array}$ & $\begin{array}{c}(3) \\
\text { Work-luck }\end{array}$ & $\begin{array}{c}(4) \\
\text { Party } \\
\text { affiliation }\end{array}$ & $\begin{array}{c}(5) \\
\text { Political } \\
\text { views }\end{array}$ & $\begin{array}{c}(6) \\
\text { Voting democrat }\end{array}$ & $\begin{array}{c}(7) \\
\text { AES } \\
\text { Pref. } \\
\text { redistr. }\end{array}$ & $\begin{array}{c}(8) \\
\text { AES } \\
\text { Pol. } \\
\text { behav. }\end{array}$ & $\begin{array}{c}(9) \\
\text { AES } \\
\text { All }\end{array}$ \\
\hline Economic shock & $\begin{array}{c}0.024 \\
(0.020)\end{array}$ & $\begin{array}{c}0.051 * * * \\
(0.017)\end{array}$ & $\begin{array}{l}0.024^{*} \\
(0.012)\end{array}$ & $\begin{array}{c}0.175^{* * *} \\
(0.027)\end{array}$ & $\begin{array}{c}0.144 * * * \\
(0.030)\end{array}$ & $\begin{array}{c}0.048^{* * *} \\
(0.008)\end{array}$ & $\begin{array}{c}0.045^{* * *} \\
(0.011)\end{array}$ & $\begin{array}{c}0.094 * * * \\
(0.015)\end{array}$ & $\begin{array}{c}0.068^{* * *} \\
(0.009)\end{array}$ \\
\hline Years educ. & $\begin{array}{c}-0.038^{* * *} \\
(0.008)\end{array}$ & $\begin{array}{c}-0.015^{* * *} \\
(0.004)\end{array}$ & $\begin{array}{l}0.005^{*} \\
(0.003)\end{array}$ & $\begin{array}{c}-0.021 * * * \\
(0.007)\end{array}$ & $\begin{array}{l}0.015^{*} \\
(0.009)\end{array}$ & $\begin{array}{c}0.005^{* *} \\
(0.002)\end{array}$ & & & \\
\hline Married & $\begin{array}{c}-0.115^{* * *} \\
(0.019)\end{array}$ & $\begin{array}{c}-0.045^{* * *} \\
(0.016)\end{array}$ & $\begin{array}{c}-0.055^{* * *} \\
(0.012)\end{array}$ & $\begin{array}{c}-0.145^{* * *} \\
(0.025)\end{array}$ & $\begin{array}{c}-0.213 * * * \\
(0.016)\end{array}$ & $\begin{array}{c}-0.035^{* * *} \\
(0.009)\end{array}$ & & & \\
\hline Female & $\begin{array}{c}0.183 * * * \\
(0.021)\end{array}$ & $\begin{array}{c}0.074 * * * \\
(0.017)\end{array}$ & $\begin{array}{c}-0.053 * * * \\
(0.015)\end{array}$ & $\begin{array}{c}0.180^{* * *} \\
(0.045)\end{array}$ & $\begin{array}{c}0.126^{* * *} \\
(0.021)\end{array}$ & $\begin{array}{c}0.039 * * * \\
(0.010)\end{array}$ & & & \\
\hline Black & $\begin{array}{c}0.646^{* * *} \\
(0.044)\end{array}$ & $\begin{array}{c}0.297 * * * \\
(0.024)\end{array}$ & $\begin{array}{c}0.120 * * * \\
(0.030)\end{array}$ & $\begin{array}{c}1.611^{* * *} \\
(0.055)\end{array}$ & $\begin{array}{c}0.438^{* * *} \\
(0.027)\end{array}$ & $\begin{array}{c}0.498^{* * *} \\
(0.008)\end{array}$ & & & \\
\hline Unemployed & $\begin{array}{c}0.132 * * * \\
(0.029)\end{array}$ & $\begin{array}{c}0.097 * * * \\
(0.028)\end{array}$ & $\begin{array}{c}0.017 \\
(0.012)\end{array}$ & $\begin{array}{l}0.088^{*} \\
(0.048)\end{array}$ & $\begin{array}{c}0.067 \\
(0.049)\end{array}$ & $\begin{array}{c}0.045^{* * *} \\
(0.013)\end{array}$ & & & \\
\hline Father years educ. & $\begin{array}{c}-0.014^{* * *} \\
(0.003)\end{array}$ & $\begin{array}{c}-0.005^{* *} \\
(0.002)\end{array}$ & $\begin{array}{c}0.000 \\
(0.001)\end{array}$ & $\begin{array}{c}-0.037 * * * \\
(0.004)\end{array}$ & $\begin{array}{c}0.000 \\
(0.003)\end{array}$ & $\begin{array}{c}-0.006 * * * \\
(0.001)\end{array}$ & & & \\
\hline Income fixed effects & yes & yes & yes & yes & yes & yes & yes & yes & yes \\
\hline Age fixed effects & yes & yes & yes & yes & yes & yes & yes & yes & yes \\
\hline Year fixed effects & yes & yes & yes & yes & yes & yes & yes & yes & yes \\
\hline Cohort fixed effects & yes & yes & yes & yes & yes & yes & yes & yes & yes \\
\hline Region interview f.e. & yes & yes & yes & yes & yes & yes & yes & yes & yes \\
\hline Regionxyear interact. & yes & yes & yes & yes & yes & yes & yes & yes & yes \\
\hline Region at 16 f.e. & yes & yes & yes & yes & yes & yes & yes & yes & yes \\
\hline (Region at 16 )*age & yes & yes & yes & yes & yes & yes & yes & yes & yes \\
\hline Income at 16 dummies & yes & yes & yes & yes & yes & yes & yes & yes & yes \\
\hline Religion at 16 dummies & yes & yes & yes & yes & yes & yes & yes & yes & yes \\
\hline Religion dummies & yes & yes & yes & yes & yes & yes & yes & yes & yes \\
\hline Observations & 13304 & 8036 & 17313 & 24827 & 21763 & 16523 & 12884 & 21038 & 16961 \\
\hline R-squared & 0.10 & 0.08 & 0.03 & 0.15 & 0.10 & 0.19 & & & \\
\hline
\end{tabular}

Notes: [1] Standard errors are clustered at the region at 16 level, and estimated using the wild bootstrap method; $*$ significant at $10 \%$, $* *$ significant at $5 \%$, *** significant at 1\%. [2] Religion (and religion at 16) dummies include Protestants, Catholics, Christians, Jewish and Other religions. The excluded group is given by 
individuals who are not religious; [3] the number of observations reported for the AES in columns 7, 8 and 9 is the average number of observations in the regressions for the measures of preferences for redistribution, political behavior, or all of them respectively.

Table 4

GSS: Baseline Specification for Other Age Ranges

\begin{tabular}{|c|c|c|c|c|c|c|c|c|c|}
\hline \multicolumn{10}{|c|}{ Age range 14-18 } \\
\hline & $\begin{array}{c}(1) \\
\text { Help poor }\end{array}$ & $\begin{array}{c}\text { (2) } \\
\text { Assistance } \\
\text { poor }\end{array}$ & $\begin{array}{c}(3) \\
\text { Work- } \\
\text { luck }\end{array}$ & $\begin{array}{c}\text { (4) } \\
\text { Party } \\
\text { identification }\end{array}$ & $\begin{array}{c}(5) \\
\text { Political } \\
\text { Views }\end{array}$ & $\begin{array}{c}(6) \\
\text { Voting } \\
\text { democrat }\end{array}$ & $\begin{array}{c}(7) \\
\text { AES } \\
\text { Pref. red. }\end{array}$ & $\begin{array}{c}\text { (8) } \\
\text { AES } \\
\text { Pol. beh. }\end{array}$ & $\begin{array}{c}(9) \\
\text { AES } \\
\text { All }\end{array}$ \\
\hline $\begin{array}{l}\text { Economic shock } \\
\text { Observations } \\
\text { R-squared }\end{array}$ & $\begin{array}{c}-0.049 \\
(0.040) \\
20949 \\
0.10 \\
\end{array}$ & $\begin{array}{c}0.019 \\
(0.047) \\
14916 \\
0.08 \\
\end{array}$ & $\begin{array}{c}-0.010 \\
(0.016) \\
26082 \\
0.02 \\
\end{array}$ & $\begin{array}{c}0.028 \\
(0.077) \\
40869 \\
0.11 \\
\end{array}$ & $\begin{array}{c}0.011 \\
(0.053) \\
36375 \\
0.05 \\
\end{array}$ & $\begin{array}{c}0.014 \\
(0.012) \\
25316 \\
0.16 \\
\end{array}$ & $\begin{array}{c}-0.010 \\
(0.041) \\
20649\end{array}$ & $\begin{array}{c}0.017 \\
(0.040) \\
34187\end{array}$ & $\begin{array}{c}0.004 \\
(0.039) \\
27418\end{array}$ \\
\hline \multicolumn{10}{|c|}{ Age range 2-9 } \\
\hline $\begin{array}{l}\text { Economic shock } \\
\text { Observations } \\
\text { R-squared }\end{array}$ & $\begin{array}{c}-0.056 \\
(0.047) \\
20068 \\
0.10\end{array}$ & $\begin{array}{c}0.011 \\
(0.025) \\
14399 \\
0.08\end{array}$ & $\begin{array}{c}-0.011 \\
(0.018) \\
24773 \\
0.02\end{array}$ & $\begin{array}{c}0.069 \\
(0.075) \\
38931 \\
0.11\end{array}$ & $\begin{array}{c}-0.016 \\
(0.053) \\
34697 \\
0.06\end{array}$ & $\begin{array}{c}-0.008 \\
(0.034) \\
23872 \\
0.16\end{array}$ & $\begin{array}{l}-0.016 \\
(0.020) \\
19747\end{array}$ & $\begin{array}{c}0.003 \\
(0.034) \\
32500\end{array}$ & $\begin{array}{c}-0.007 \\
(0.015) \\
26123\end{array}$ \\
\hline \multicolumn{10}{|c|}{ Age range 10-17 } \\
\hline $\begin{array}{l}\text { Economic shock } \\
\text { Observations } \\
\text { R-squared }\end{array}$ & $\begin{array}{c}-0.028 \\
(0.049) \\
21320 \\
0.10\end{array}$ & $\begin{array}{c}0.031 \\
(0.039) \\
15125 \\
0.08\end{array}$ & $\begin{array}{c}-0.018 \\
(0.022) \\
26741 \\
0.02\end{array}$ & $\begin{array}{c}-0.106^{* *} \\
(0.052) \\
41804 \\
0.11 \\
\end{array}$ & $\begin{array}{c}-0.074 * * \\
(0.035) \\
37167 \\
0.05 \\
\end{array}$ & $\begin{array}{c}-0.020 \\
(0.018) \\
26035 \\
0.16\end{array}$ & $\begin{array}{c}-0.002 \\
(0.020) \\
21062\end{array}$ & $\begin{array}{c}-0.049 \\
(0.044) \\
35002\end{array}$ & $\begin{array}{c}-0.025 \\
(0.028) \\
28032\end{array}$ \\
\hline \multicolumn{10}{|c|}{ Age range 26-33 } \\
\hline $\begin{array}{l}\text { Economic shock } \\
\text { Observations } \\
\text { R-squared }\end{array}$ & $\begin{array}{c}-0.136 * \\
(0.074) \\
21119 \\
0.10 \\
\end{array}$ & $\begin{array}{c}-0.075 \\
(0.069) \\
14516 \\
0.08 \\
\end{array}$ & $\begin{array}{c}0.086 * * \\
(0.036) \\
27289 \\
0.02 \\
\end{array}$ & $\begin{array}{c}0.252^{* * *} \\
(0.071) \\
42201 \\
0.11 \\
\end{array}$ & $\begin{array}{c}0.181 * * * \\
(0.057) \\
37432 \\
0.05 \\
\end{array}$ & $\begin{array}{c}0.027 * \\
(0.016) \\
27059 \\
0.15\end{array}$ & $\begin{array}{l}-0.034 \\
(0.050) \\
20975\end{array}$ & $\begin{array}{c}0.105 * * * \\
(0.039) \\
35564\end{array}$ & $\begin{array}{c}0.035 \\
(0.038) \\
28269\end{array}$ \\
\hline \multicolumn{10}{|c|}{ Age range $34-41$} \\
\hline $\begin{array}{l}\text { Economic shock } \\
\text { Observations } \\
\text { R-squared }\end{array}$ & $\begin{array}{c}0.021 \\
(0.069) \\
19456 \\
0.10\end{array}$ & $\begin{array}{c}-0.037 \\
(0.047) \\
13049 \\
0.08\end{array}$ & $\begin{array}{c}-0.028 \\
(0.028) \\
25538 \\
0.02\end{array}$ & $\begin{array}{c}-0.064 \\
(0.099) \\
39244 \\
0.11\end{array}$ & $\begin{array}{c}0.045 \\
(0.119) \\
34854 \\
0.05\end{array}$ & $\begin{array}{c}-0.032 \\
(0.023) \\
25664 \\
0.15\end{array}$ & $\begin{array}{c}-0.026 \\
(0.045) \\
19348\end{array}$ & $\begin{array}{c}-0.021 \\
(0.034) \\
33254\end{array}$ & $\begin{array}{c}-0.023 \\
(0.036) \\
26301\end{array}$ \\
\hline
\end{tabular}




\begin{tabular}{|c|c|c|c|c|c|c|c|c|c|}
\hline \multicolumn{10}{|c|}{ Age range 42-49 } \\
\hline Economic shock & 0.255 & $0.143 * *$ & -0.055 & $-0.328 * *$ & $-0.277 * * *$ & 0.053 & 0.114 & $-0.087^{*}$ & 0.013 \\
\hline & $(0.165)$ & $(0.067)$ & $(0.074)$ & $(0.134)$ & $(0.060)$ & $(0.042)$ & $(0.113)$ & $(0.053)$ & $(0.076)$ \\
\hline Observations & 16347 & 10538 & 22337 & 34058 & 30140 & 23014 & 16407 & 29071 & 22739 \\
\hline R-squared & 0.10 & 0.08 & 0.02 & 0.11 & 0.06 & 0.15 & & & \\
\hline \multicolumn{10}{|c|}{ Age range 50-57 } \\
\hline Economic shock & -0.189 & -0.074 & $0.189 *$ & $-0.360^{*}$ & -0.217 & -0.068 & 0.002 & $-0.157 * *$ & -0.077 \\
\hline & $(0.301)$ & $(0.146)$ & $(0.113)$ & $(0.207)$ & $(0.207)$ & $(0.053)$ & $(0.141)$ & $(0.068)$ & $(0.079)$ \\
\hline Observations & 12121 & 7645 & 17652 & 26493 & 23267 & 18874 & 12473 & 22878 & 17675 \\
\hline R-squared & 0.11 & 0.09 & 0.02 & 0.11 & 0.06 & 0.15 & & & \\
\hline
\end{tabular}

Notes: [1] Standard errors are clustered at the region at 16 level, and estimated using the wild bootstrap method; ${ }^{*}$ significant at $10 \%,{ }^{* *}$ significant at $5 \%$, *** significant at $1 \%$; [2] the specification corresponds to the baseline specification of Table 1; [3] the number of observations reported for the AES in columns 7, 8 and 9 is the average number of observations in the regressions for the measures of preferences for redistribution, political behavior, or all of them respectively. 
Table 5

World Value Survey: Baseline specification

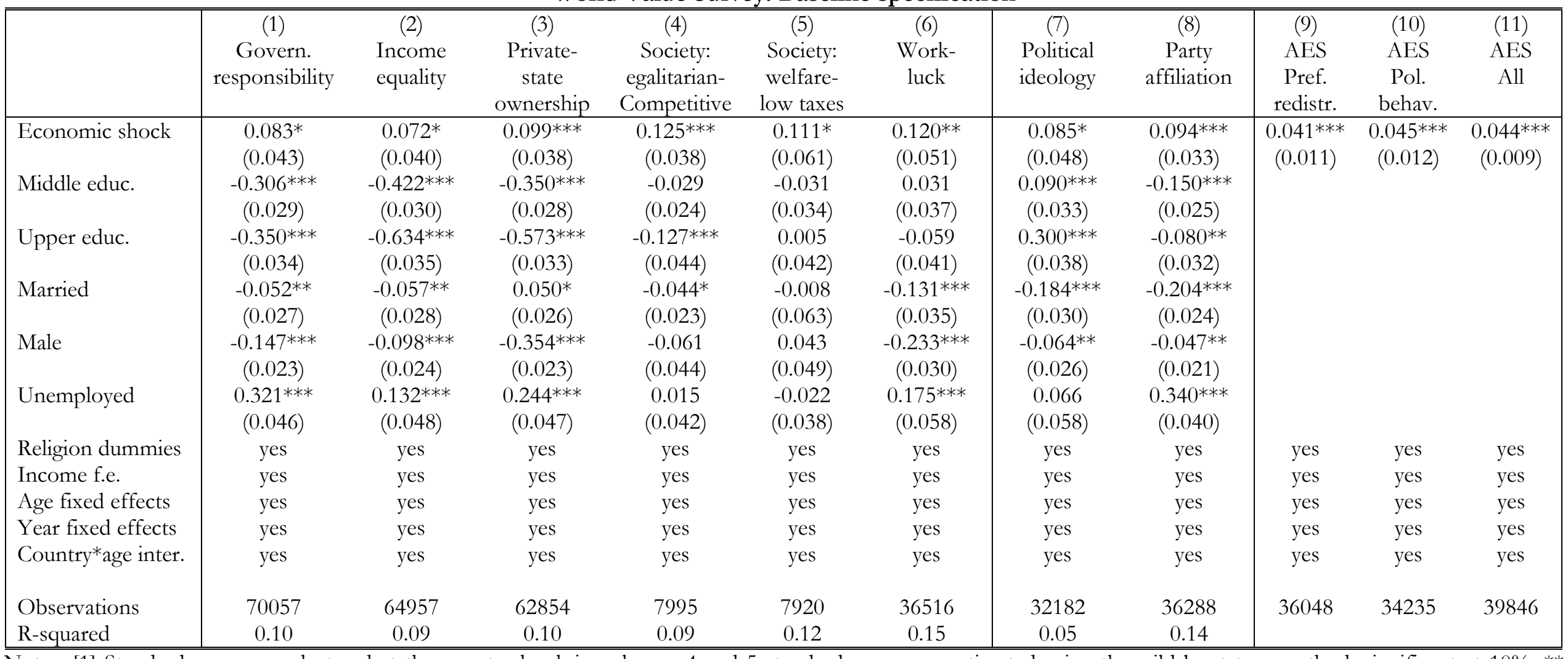

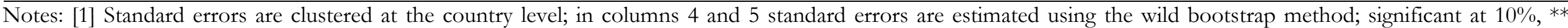

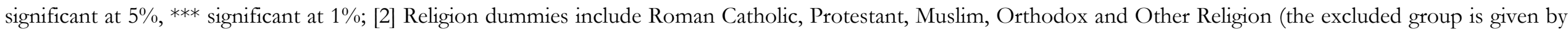

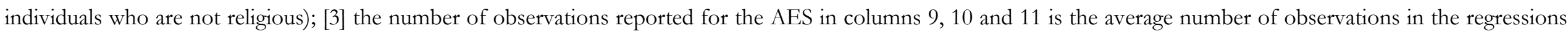
for the measures of preferences for redistribution, political behavior, or all of them respectively. 


\section{Table 6}

NLS72: Baseline Specification

\begin{tabular}{|c|c|c|}
\hline Unemployment-imp. years & $\begin{array}{c}(1) \\
\text { Work-luck } \\
0.017^{* * *} \\
(0.004)\end{array}$ & $\begin{array}{c}(2) \\
\text { Work-luck }\end{array}$ \\
\hline Unemployment-at 32 years & $\begin{array}{l}-0.002 \\
(0.004)\end{array}$ & \\
\hline Recession-imp. years & & $\begin{array}{c}0.064 * * * \\
(0.015)\end{array}$ \\
\hline Recession-at 32 years & & $\begin{array}{l}-0.032 \\
(0.021)\end{array}$ \\
\hline College & $\begin{array}{l}-0.005 \\
(0.014)\end{array}$ & $\begin{array}{l}-0.005 \\
(0.013)\end{array}$ \\
\hline Married & $\begin{array}{c}-0.038^{* * *} \\
(0.008)\end{array}$ & $\begin{array}{c}-0.039 * * * \\
(0.008)\end{array}$ \\
\hline Male & $\begin{array}{c}0.077 * * * \\
(0.011)\end{array}$ & $\begin{array}{c}0.077^{* * *} * \\
(0.011)\end{array}$ \\
\hline Unemployed & $\begin{array}{c}0.048^{* *} \\
(0.024)\end{array}$ & $\begin{array}{c}0.049^{* *} \\
(0.024)\end{array}$ \\
\hline Black & $\begin{array}{c}0.157 * * * \\
(0.023)\end{array}$ & $\begin{array}{c}0.157 * * * \\
(0.023)\end{array}$ \\
\hline Log (pers. income) & $\begin{array}{l}-0.004^{*} \\
(0.002)\end{array}$ & $\begin{array}{c}-0.004 * \\
(0.002)\end{array}$ \\
\hline Log (fam. income at 18) & $\begin{array}{c}-0.022 * * \\
(0.010)\end{array}$ & $\begin{array}{c}-0.021^{* *} \\
(0.010)\end{array}$ \\
\hline Father less than high school & $\begin{array}{c}0.004 \\
(0.012)\end{array}$ & $\begin{array}{c}0.004 \\
(0.012)\end{array}$ \\
\hline Academic & $\begin{array}{c}-0.034 * * * \\
(0.011)\end{array}$ & $\begin{array}{c}-0.033^{* * *} * \\
(0.011)\end{array}$ \\
\hline Grade & $\begin{array}{c}-0.003 * * * \\
(0.001)\end{array}$ & $\begin{array}{c}-0.003^{* * *} \\
(0.001)\end{array}$ \\
\hline Working in high school & $\begin{array}{c}-0.003^{* * *} \\
(0.001)\end{array}$ & $\begin{array}{c}-0.003^{* * *} \\
(0.001)\end{array}$ \\
\hline Religion dummies & yes & yes \\
\hline State fixed effects & yes & yes \\
\hline Year fixed effects & yes & yes \\
\hline Observations & 23684 & 23684 \\
\hline R-squared & 0.03 & 0.03 \\
\hline
\end{tabular}


Table 7

NLS72: Interactions with Personal Background

\begin{tabular}{|c|c|c|c|c|c|c|c|c|}
\hline & $\begin{array}{c}(1) \\
\text { Work- } \\
\text { luck }\end{array}$ & $\begin{array}{c}(2) \\
\text { Work- } \\
\text { luck }\end{array}$ & $\begin{array}{c}(3) \\
\text { Work- } \\
\text { luck }\end{array}$ & $\begin{array}{c}(4) \\
\text { Work- } \\
\text { luck }\end{array}$ & $\begin{array}{c}\text { (5) } \\
\text { Work- } \\
\text { luck }\end{array}$ & $\begin{array}{c}(6) \\
\text { Work- } \\
\text { luck }\end{array}$ & $\begin{array}{c}(7) \\
\text { Work- } \\
\text { luck }\end{array}$ & $\begin{array}{c}(8) \\
\text { Work- } \\
\text { luck }\end{array}$ \\
\hline Unempl. - imp. years & $\begin{array}{c}0.016^{* * *} \\
(0.004)\end{array}$ & $\begin{array}{c}0.016^{* * *} \\
(0.005)\end{array}$ & $\begin{array}{c}0.018^{* * *} \\
(0.005)\end{array}$ & $\begin{array}{c}0.017 * * * \\
(0.004)\end{array}$ & $\begin{array}{c}0.020^{* * *} \\
(0.004)\end{array}$ & $\begin{array}{c}0.063^{* * *} \\
(0.016)\end{array}$ & $\begin{array}{c}0.018^{* * *} \\
(0.005)\end{array}$ & $\begin{array}{c}0.017 * * \\
(0.007)\end{array}$ \\
\hline Unempl. - at 32 years & $\begin{array}{l}-0.002 \\
(0.004)\end{array}$ & $\begin{array}{l}-0.002 \\
(0.004)\end{array}$ & $\begin{array}{l}-0.002 \\
(0.004)\end{array}$ & $\begin{array}{l}-0.002 \\
(0.004)\end{array}$ & $\begin{array}{l}-0.001 \\
(0.005)\end{array}$ & $\begin{array}{l}-0.003 \\
(0.004)\end{array}$ & $\begin{array}{l}-0.002 \\
(0.004)\end{array}$ & $\begin{array}{l}-0.002 \\
(0.004)\end{array}$ \\
\hline Black*(unem. i.y.) & $\begin{array}{c}0.010 \\
(0.007)\end{array}$ & & & & & & & \\
\hline Black & $\begin{array}{c}0.106^{* * *} \\
(0.037)\end{array}$ & & & & & & & \\
\hline Male*(unem. i.y.) & & $\begin{array}{c}0.003 \\
(0.003)\end{array}$ & & & & & & \\
\hline Male & & $\begin{array}{c}0.060^{* * *} \\
(0.016)\end{array}$ & & & & & & \\
\hline $\log ($ fam. inc. at 18$) *$ (un. i.y.) & & & $\begin{array}{l}-0.001 \\
(0.002)\end{array}$ & & & & & \\
\hline $\log ($ fam. inc. at 18$)$ & & & $\begin{array}{l}-0.014 \\
(0.020)\end{array}$ & & & & & \\
\hline (Father less h.s.)*(un. i.y.) & & & & $\begin{array}{c}0.001 \\
(0.002)\end{array}$ & & & & \\
\hline Father less than high school & & & & $\begin{array}{l}-0.002 \\
(0.016)\end{array}$ & & & & \\
\hline Academic*(un. i.y.) & & & & & $\begin{array}{c}-0.006 * * \\
(0.003)\end{array}$ & & & \\
\hline Academic & & & & & $\begin{array}{l}-0.003 \\
(0.018)\end{array}$ & & & \\
\hline Grade*(un. i.y.) & & & & & & $\begin{array}{c}-0.001^{* * *} \\
(0.000)\end{array}$ & & \\
\hline Grade & & & & & & $\begin{array}{l}-0.000 \\
(0.001)\end{array}$ & & \\
\hline$($ Working in h.s.)*(un. i.y.) & & & & & & & $\begin{array}{l}-0.000 \\
(0.000)\end{array}$ & \\
\hline Working in high school & & & & & & & $\begin{array}{c}-0.003 * * * \\
(0.001)\end{array}$ & \\
\hline Protestant & & & & & & & & $\begin{array}{c}-0.069 * \\
(0.041)\end{array}$ \\
\hline Roman Catholic & & & & & & & & $\begin{array}{l}-0.043 \\
(0.038)\end{array}$ \\
\hline Other Christian & & & & & & & & $\begin{array}{l}-0.073 \\
(0.047)\end{array}$ \\
\hline Jewish & & & & & & & & $\begin{array}{l}0.127^{*} \\
(0.065)\end{array}$ \\
\hline Other & & & & & & & & $\begin{array}{l}-0.085 \\
(0.058)\end{array}$ \\
\hline Protestant*un_iy & & & & & & & & $\begin{array}{c}0.001 \\
(0.006)\end{array}$ \\
\hline
\end{tabular}




\begin{tabular}{|c|c|c|c|c|c|c|c|c|}
\hline Roman Catholic*un_iy & & & & & & & & $\begin{array}{c}0.002 \\
(0.006)\end{array}$ \\
\hline Other Christian*un_iy & & & & & & & & $\begin{array}{c}0.002 \\
(0.007)\end{array}$ \\
\hline Jewish*un_iy & & & & & & & & $\begin{array}{c}-0.021 * \\
(0.010)\end{array}$ \\
\hline Other*un_iy & & & & & & & & $\begin{array}{c}0.004 \\
(0.009)\end{array}$ \\
\hline State fixed effects & yes & yes & Yes & yes & yes & yes & yes & Yes \\
\hline Year fixed effects & yes & yes & Yes & yes & yes & yes & yes & Yes \\
\hline Observations & 23684 & 23684 & 23684 & 23684 & 23684 & 23684 & 23684 & 23684 \\
\hline R-squared & 0.03 & 0.03 & 0.03 & 0.03 & 0.03 & 0.03 & 0.03 & 0.03 \\
\hline
\end{tabular}

Notes: [1] Standard errors are clustered at the state level; * significant at $10 \%,{ }^{* *}$ significant at $5 \%,{ }^{* * *}$ significant at $1 \%$

Table 8

NLS72: Interactions with Personal Experience during Impressionable Years

\begin{tabular}{|c|c|c|c|c|}
\hline & $\begin{array}{c}(1) \\
\text { Work-luck }\end{array}$ & $\begin{array}{c}(2) \\
\text { Work-luck }\end{array}$ & $\begin{array}{c}(3) \\
\text { Work-luck }\end{array}$ & $\begin{array}{c}(4) \\
\text { Work-luck }\end{array}$ \\
\hline Unempl. - imp. years & $\begin{array}{c}0.018^{* * *} \\
(0.004)\end{array}$ & $\begin{array}{c}0.018^{* * *} \\
(0.004)\end{array}$ & $\begin{array}{c}0.019 * * * \\
(0.004)\end{array}$ & $\begin{array}{c}0.031 * * * \\
(0.008)\end{array}$ \\
\hline Unempl. - at 32 years & $\begin{array}{l}-0.003 \\
(0.004)\end{array}$ & $\begin{array}{l}-0.002 \\
(0.004)\end{array}$ & $\begin{array}{l}-0.003 \\
(0.004)\end{array}$ & $\begin{array}{l}-0.002 \\
(0.004)\end{array}$ \\
\hline Unemployed*(unempl. i. y.) & $\begin{array}{l}-0.006 \\
(0.006)\end{array}$ & & & \\
\hline Unemployed & $\begin{array}{l}0.083^{*} \\
(0.042)\end{array}$ & & & \\
\hline College*(unempl. i.y.) & & $\begin{array}{c}-0.009 * * \\
(0.004)\end{array}$ & & \\
\hline College & & $\begin{array}{c}0.024 \\
(0.018)\end{array}$ & & \\
\hline Married*(unempl. i.y.) & & & $\begin{array}{l}-0.004 \\
(0.003)\end{array}$ & \\
\hline Married & & & $\begin{array}{l}-0.016 \\
(0.019)\end{array}$ & \\
\hline $\log \left(\right.$ pers. income) ${ }^{*}$ (unemp. i.y.) & & & & $\begin{array}{c}-0.002^{* *} \\
(0.001)\end{array}$ \\
\hline Log (pers. income) & & & & $\begin{array}{c}0.005 \\
(0.004)\end{array}$ \\
\hline Religion dummies & yes & yes & yes & yes \\
\hline State fixed effects & yes & yes & yes & yes \\
\hline Year fixed effects & yes & yes & yes & yes \\
\hline Observations & 23684 & 23684 & 23684 & 23684 \\
\hline R-squared & 0.03 & 0.03 & 0.03 & 0.03 \\
\hline
\end{tabular}

